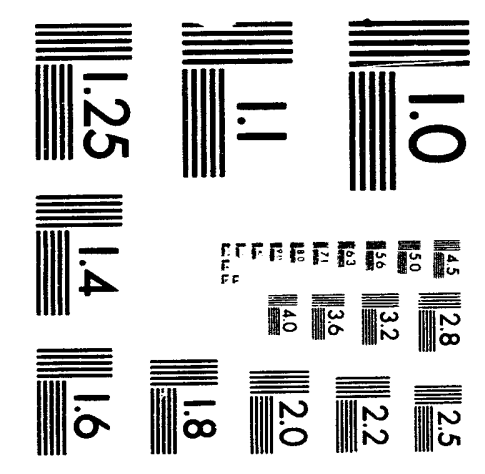



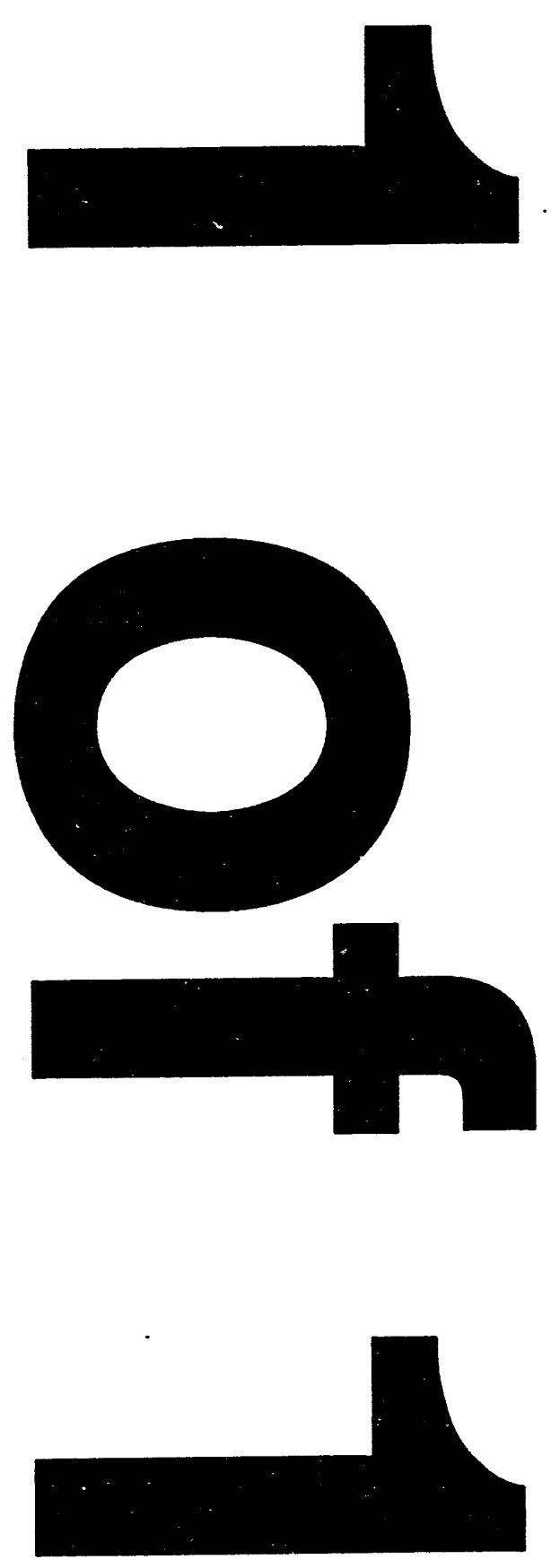


\title{
PROPOSAL
}

for a new program leading to the

\section{Masírer of Science Degree}

in

\author{
Environmental Studies
}

to be offered jointly by the

\section{Medical University of South Carolina}

and the

\section{University of Charleston, South Carolina}

\author{
DISCLAIMER
}

\begin{abstract}
This report was prepared as an account of work sponsored by an agency of the Unitw' States Government. Neither the United States Government nor any agency thereof, nor any of their Government. Neither the United States Government nor any agency the legal liability or responsibility for the accuracy, completeness, or usefulness of any information, apparatus, product, or process disclosed, or represents that its use would not infringe privately owned rights. Reference herein to any specific commercial product, process, or service by trade name, trademark, manufacturer, or otherwise does not necessarily constitute or imply its endorsement, recommendation, or favoring by the United States Government or any agency thereof. The views and opinions of authors expressed herein do not necessarily state or reflect those of the United States Government or any agency thereof.
\end{abstract}




\section{Table of Contents}

I. Classification

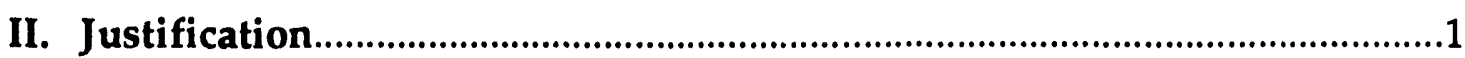

A. Statement of Purposes and Objectives..................................................1

B. Centrality to the Mission of the Institutions........................................

C. Relationship to Other Programs Within MUSC and UCSC.............4

D. Relation to Similar Programs at Other Institutions............................6

E. Needs Assessment.................................................................................7

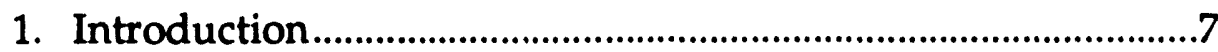

2. Prospective Student Pool ..........................................................

3. Employment Opportunities for Graduates ……..........................10

Table 1: EMPLOYMENT PROJECTIONS.........................................11

Table 2: MANPOWER NEED PROJECTIONS FOR 1997..............12

Table 3: JOBS AND SALARY EXPECTATIONS..............................13

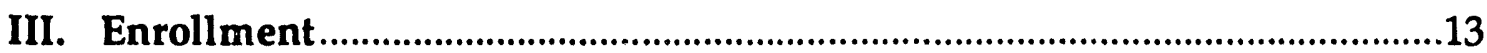

A. Anticipated Enrollment..........................................................................13

Table 4: PROJECTED ENROLLMENT.......................................14

B. Discussion of Estimates...................................................................14

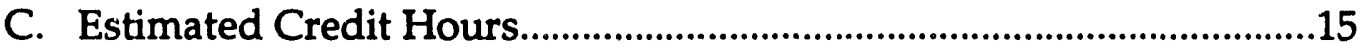

Table 5: ESTIMATED CREDIT HOURS.........................................15

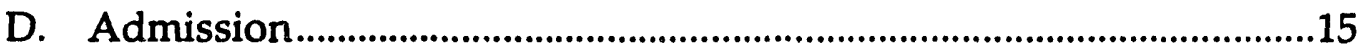

1. Minimum Standards for Admission .......................................15

2. Specific admission requirements ..................................................16

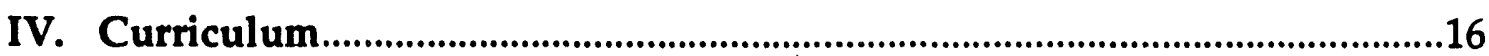

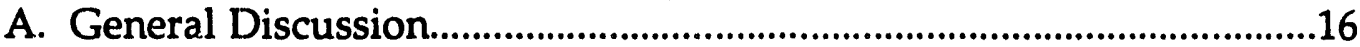

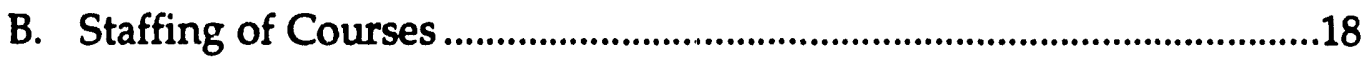

C. Degree Requirements..............................................................................19

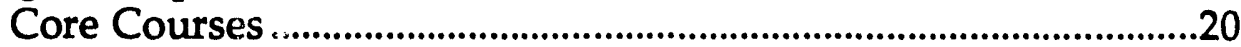

Other Requirements............................................................................21

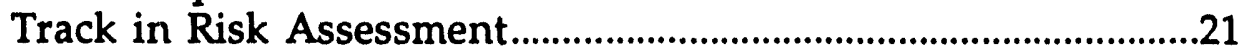

Track in Environmental Policy ..........................................................21

Track in Environmental Science..................................................21

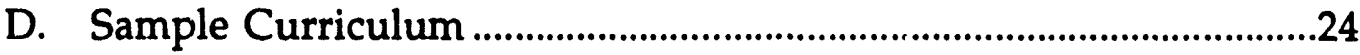

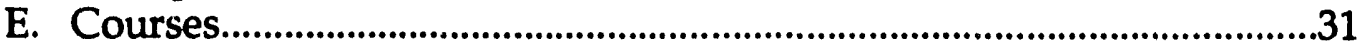

1. New Courses to be Added............................................................31

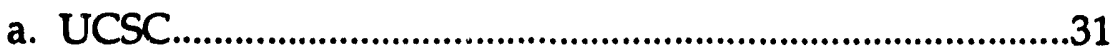

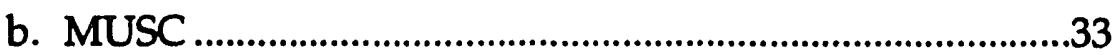

2. Existing Courses Relevant to the Program...............................36

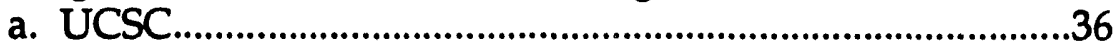

b. MUSC .................................................................................. 


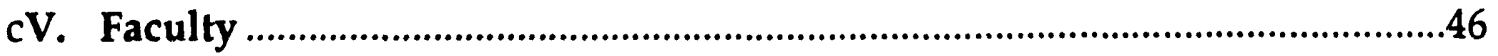

A. Graduate Faculty Status.......................................................................46

B. Current Faculty .......................................................................................47

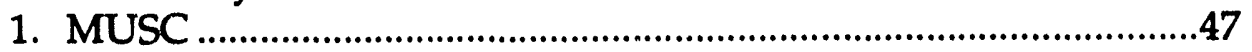

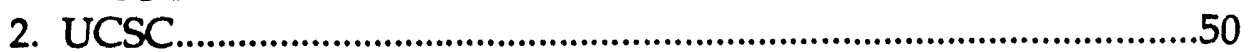

C. Qualification of New Faculty...................................................................54

D. Proposed Changes in Assignment ....................................................54

E. Table of Current and New Faculty........................................................55

Table 6: DISTRIBUTION OF FTE'S..........................................56

F. Faculty Development .............................................................................56

Teaching.............................................................................................57

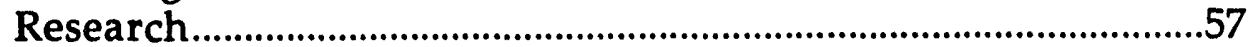

Science Communication..................................................................57

G. Administration of Program...................................................................58

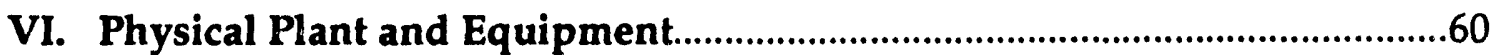

A. Space ...................................................................................................60

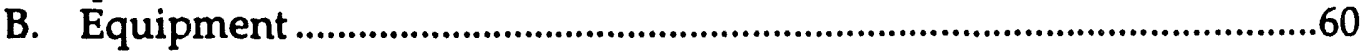

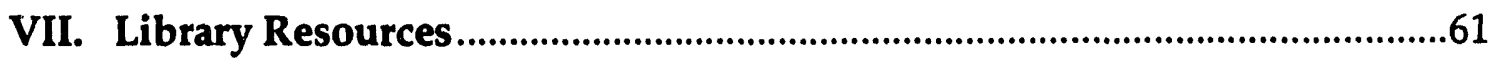

A. Current Holdings...........................................................................................61

1. Library Resources at MUSC .........................................................61

2. Library Resources at UCSC .........................................................62

B. Qualitative Assessment......................................................................62

C. Estimate of Needed Acquisitions..................................................................63

VIII. Accreditation, Approval, Licensure, or Certification ...............................67

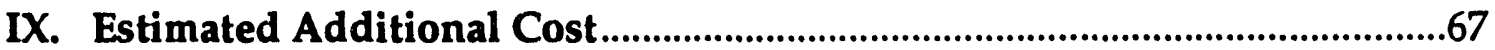

A. Table of Expenditures ................................................................................67

Table 7: ESTIMATED BUDGET........................................................68

B. Sources of External Funds..........................................................................69

C. Unique Costs ................................................................................................72

D. Relationship to Deficiencies in Current Programs...............................72

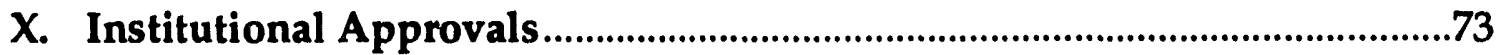




\section{ClassificAtion}

The Medical University of South Carolina (MUSC) and the University of Charleston, South Carolina (UCSC) propose to offer the degree of Master of Science in Environmental Studies. The proposed starting date is August 1994. The program is truly interdisciplinary and falls in several categories. The main category is 03.01 (Natural Resources Conservation, General) of the USDE's Classification of Instructiona! Programs, and specifically in the subclasses 03.0102 (Environmental Science/Studies) and 03.0201 Natural Resource Management and Policy). Secondary classifications are 26.0614 (Biometrics), 26.0615 (Biostatistics), 30.01 (Multidisciplinary Studies/Biological and Physical Science), 30.06 (Multidisciplinary Studies/Systems Science and Theory), 51.1303 (Medical Biomathematics and Biometrics), 51.2202 (Environmental Health), 51.2203 (Epidemiology), and 51.2204 (Health and Medical Biostatistics). Students will be able to select programs of study in Environmental Policy, Environmental Science, and Environmental Risk Assessment.

\section{JUSTIFICATION}

\section{A. Statement of Purposes and Objectives}

The purpose of this interdisciplinary program is to offer nationally and internationally recognized graduate level training in the areas of environmental policy, science, and health risk assessment, leading to the Master of Science degree in Environmental Studies. Special emphasis will be placed on human health. The rapid growth of the population in the Charle ton metropolitan area is similar to that of many cities in the coastal areas of the United States. This growth has prompted increased concern over the impact of large human populations on fragile natural ecosystems that are some of the most productive in the world. Furthermore, the growth of the human population has prompted concerns for human health where needs for food and recreation can be at odds with an equally important requirement to produce food using aquacultural and agricultural techniques. Nowhere are the issues of managing resources to provide for the long-term welfare of humans more poignantly focused than in the coastal regions surrounding Charleston. Policy makers and managers of environmental resources must work with scientists to pose the correct questions and to obtain answers to those questions in a timely fashion before crises strike. Scientists must become better aware of the political and economic climates that mold the decisions of government officials, resource managers and politicians. The proposed graduate program in Environmental Studies will focus the intellectual efforts of two prominent academic institutions in cooperation with local industries and other agencies to the training of students who will be the environmental practitioners of the coming decades. The study of environmental issues has become basic to the curriculum of any campus. The Charleston area is currently lacking in any programs in environmental studies 
and there is a large local demand for such programs. This demand is both from the full-time student and from part-time or non traditional students for whom it is not practical to travel to another local. The expertise for offering such a program is currently present on the facilities of MUSC and UCSC.

In December of 1991, the Office of Environmental Restoration and Waste Management of the Department of Energy issued an Environmental Education Strategic Plan outlining overall needs and initiatives for education about the environment in the United States (Document DOE/EM-0058P). The three major components of the plan are:

1) Meeting future work force demand by increasing/enhancing the flow of appropriately trained and educated people from the education pipeline (K-graduate school);

2) Training and retraining the current work force; and

3) Creating and maintaining environmentally literate public through outreach and professional societies.

A significant part of this emphasis is education in risk assessment. A 1983 document by the National Research Council's Committee on the Institution of Means for the Assessment of Crisis to Public Health defines risk assessment as a multistep process comprising the following tasks:

1) Hazard Assessment: Identification of toxic chemicals of health concern and their potential health effects;

2) Dose-Response Assessment: Quantitative estimation of the relationship between the dose of a substance and the probability of an adverse health effect;

3) Exposure Assessment: Characterization of populations exposed to toxic chemicals of concern, pathways, duration, frequency of exposure;

4) Risk Assessment: Estimation of risk for the health effect of concern, based on information from the dose-response and exposure assessment;

5) Uncertainty Analysis: Description of assumptions and limitations in each of the above steps.

The proposed program is not only offered by a multi-disciplinary array of faculty and departments at two institutions, it will be truly interdisciplinary. The core course in Environmental Health Risk Assessment will contain components of Applied Statistics, Mathematical Modeling, and Epidemiology, which all are established disciplines in their own right. A core course, offered in the basic sciences, in Environmental Biology will be co-taught by faculty from the Departments of Pharmacology and of Microbiology and Immunology at MUSC and by faculty from the Department of Biology at UCSC. The courses in the Policy area will be taught by the Institute for Public Affairs and Policy Studies at UCSC and the Department of Health Services Administration in the MUSC College of Health Related Professions. The course in Earth Systems Science will be taught by the Departments of Geology and Biology. The core course Case Studies in Environmental Science and the obligatory Capstone Seminar will be co-taught by faculty from all contributing departments at the two participating institutions. Student progress and, in particular, student internships will be 
supervised by advisory committees consisting of faculty from different departments. This type of supervision is in line with MUSC Graduate School guidelines requiring every student to include in his or her advisory committee at least two faculty from outside the student's department.

In addition to the shared responsibility for courses and student mentoring, the two institutions will initiate a lecture series on environmental topics that will be open to students and faculty from both institutions.

The interdisciplinary character of the program is further evident from the fact that research accompanying the program will be executed individually as well as jointly. Both institutions place strong emphasis on securing extramural funds for research and student training. Funds provided by the DOE grant are being considered as seed money for obtaining additional support in excess of the funds provided. MUSC and UCSC expect to submit joint proposals to various funding agencies, in addition to funds sought by individual investigators or departments.

Graduates from our program will benefit greatly from the interdisciplinary nature of our program. They will understand the hierarchical steps of environmental health risk assessment and the regulatory and policy processes in the environmental arena. They will be able to communicate with experts and the public in these and related subject areas and have the background to participate intelligently in decision-making surrounding environmental issues. The program will be available to individuals with a Bachelor's degree in Science or related areas and also, on a part-time basis, to non-traditional students. The program will also be available to $\mathrm{K}-12$ teachers and to managers of companies with environmental concerns. There is an acute local need for such courses.

\section{B. Centrality to the Mission of the Institutions}

Today's society recognizes that health and disease are not isolated issues limited to the human body, but that they are a reflection of the interactions between the body and the environment. It is becoming increasingly clear that exposure to environmental conditions plays a significant role in the well-being of our citizens, and that it is the health care provider's responsibility to explore the health effects that these environ nental conditions may have.

The health of the human population is best secured to the extent that the health of the natural environment is protected. The complex and interdisciplinary nature of environmental science is such that very few individuals have sufficiently broad training to both evaluate and manage relevant issues in the public arena. The proposed program will educate students about the relationships between health, disease, and the environment. This training is in accord with the mission of the Medical University to "serve the 
citizens of South Carolina and the nation by providing an environment for learning and discovery through education of health care professionals and biomedical scientists, research in the health sciences and provision of health care at the primary, secondary and tertiary levels." It also follows the mission of the College of Graduate Studies, which is "to train biomedical scientists for the discovery of new knowledge in a premier academic research environment." The proposed program also aids the mission of the University of Charleston. The second paragraph of the University of Charleston's Statement of Purpose adopted by the Board of Trustees in January 1991 reads: "In addition to offering a broad range of baccalaureate degree programs, the College (University) currently provides an increasing number of Master's degree programs which are compatible with the community and the state."

\section{Relationship to Other Programs Within MUSC and UCSC}

The Medical University of South Carolina offers master and doctorate-level education in the biomedical sciences. This education includes programs in basic biological areas such as anatomy and biochemistry. It also offers education in biostatistics, epidemiology, and in systems science.

The proposed program relies heavily on this existing expertise. It will be administered at the Medical University primarily by the Department of Biometry and Epidemiology (formerly Department of Biostatistics, Epidemiology, and Systems Science; DBESS) since many of the electives will be offered by this department. The most recent Review of Life Science Programs, submitted to the South Carolina Commission on Higher Education in June 1988, attests to the quality of the "broadly based, comprehensive curriculum for both undergraduate and graduate students" in Biometry \& Epidemiology (formerly "Biometry"). It states that "the Biometry Program is recognized nationally as an excellent one" and that, "because of the close supervision and attention to their needs, the students are enthusiastic and appreciative."

Other departments, including the Departments of Microbiology and Immunology, Pharmacology, Pharmaceutical Sciences, and the Departments of Environmental Health and of Health Services Administration (College of Health Professions) will participate actively in the program.

The University of Charleston offers Master's degrees in Marine Biology and Public Administration. The Institute for Public Affairs and Policy Studies at the University of Charleston and the Department of Government and International Studies at the University of South Carolina jointly offer the Master of Public Administration degree, which is delivered on the University of Charleston campus. This program is designed to train students to assume responsibilities at the local, state, and federal levels. Most graduates pursue careers in local and state administration. The joint MPA Program offers an 
ideal vehicle from which to deliver graduate courses to students in Environmental Studies because it allows effective utilization of University of South Carolina faculty to teach PUBA courses on the University of Charleston campus. The joint MPA agreement and contract between USC and UCSC currently calls for three USC faculty to come to Charleston to teach PUBA courses during the academic year as part of their nornal teaching loads. Since existing USC faculty have some expertise in acadaemic areas such as environmental politics and policy, the Joint Agreement will allow the delivery of these courses in a most cost effective manner, that is, without the need for additional faculty hires in areas of unnecessary duplication.

The newly approved Master's degree in Mathematics at the University of Charleston is already taking advantage of the strengths of the program offered by Biometry \& Epidemiology at MUSC, utilizing MUSC's statistical methods courses to supplement their course offerings.

The Marine Biology Program has produced students who have focused on basic and applied research in the environmental sciences for about 20 years. This program is administered through the Department of Biology at the University of Charleston, and the graduate faculty are broadly represented by scientists from local institutions that have long been major players in the environmental sciences including the The Citadel, the Marine Biomedical and Environmental Sciences Program of the Medical University of South Carolina, the federal National Marine Fisheries Laboratory, and the South Carolina Marine Resources Research Institute (a division of the South Carolina Wildlife and Marine Resources Division).

Undergraduate programs in the sciences at the College of Charleston are among the strongest and most popular with students. More than $10 \%$ of the undergraduate student body are science majors. Faculty in the sciences have a history of maintaining active research programs and strongly supporting undergraduate research. Undergraduates work side-by-side with faculty members in the field or the laboratory and the results of these efforts are most visible on "poster day" at the end of the academic year where students display the results of their research efforts to the academic community.

The strong connection between the new and the existing programs is evident in the fact that a number of the core courses and the envisioned electives are currently offered by the Medical University and the University of Charleston. The two institutions currently offer education in various areas of the sciences, as well as in public administration and in health risk assessment. This expertise is obviously necessary for effective teaching and student education. However, additional faculty will be necessary. This newly hired faculty will blend into the existing programs, not by creating new research areas, but by expanding the existing base into new, adjacent directions. 


\section{Relation to Similar Programs at Other Institutions}

As will be outlined in Section II E (Needs Assessment), the attempt to understand the relationships between environment, society, and health poses an overwhelming task. This task can only be accomplished through a concentrated state-wide and even national effort.

Upon recommendation of the Commission of Higher Education, MUSC has initiated work sessions, including the three research universities, the Charleston colleges and universities, and S. C. State University with the goal to establish a state-wide advisory board that will help South Carolina colleges and universities coordinate their efforts in environmental research and education. The first of these work sessions have left no doubt that all South Carolina institutions of higher education eventually will have to deal with environmental questions, not duplicating each other's efforts, but contributing, each with their particular strengths, to the overall goal of creating a better and healthier environment for the citizens of South Carolina. This envisioned statewide effort has the potential of placing South Carolina in a national leadership position. This group is working to expand to include all interested South Carolina Institutions of higher education.

If environmental education in South Carolina adheres to this vision of state-wide cooperation, we will see, ten to twenty years from now, autonomous programs throughout the state that may have a similar core curriculum but emphasize areas that are within the specific charge of each institution. For instance, Clemson University may choose to focus on environmental engineering, science and management, and ecological toxicology aspects, while MUSC will primarily focus on questions related to human health. University of South Carolina may choose to focus in geography with respect to remote sensing, environmental law, and environmental/industrial hygiene among its special interests. Very much in analogy to biochemistry, which originally developed as a subspecialty of organic chemistry but now holds a central position in the basic sciences of all major colleges and universities, a program in environmental studies now may seem to be something special and unusual, but in the future will be commonplace in institutions of higher learning.

Our discussions among the South Carolina institutions of higher education have revealed that about every school offers, explicitly or implicitly, courses that have an environmental flavor. These courses could form a nucleus for the development of environmental programs in the future. MUSC and UCSC are no exceptions. MUSC has a long tradition of offering courses in the biomedical and biometrical sciences, while UCSC has developed national reputation in areas of marine biology and public administration. These areas are central to the proposed Master's program and constitute nuclei of interdisciplinary emphases as well as specialized research and education. Of 
particular interest to us will be emphases in environmental health risk assessment and policy and in environmental questions that pertain to marine and coastal ecosystems. Nonetheless, while these are important foci, it is stressed that the proposed program is primarily interdisciplinary and multi-disciplinary in nature rather than highly specialized in one particular focus area.

From discussions with USC and Clemson, it is evident that those universities have programs currently being offered which cover aspects of the programs being proposed here. However, we again want to stress that the environmental area has evolved to a state where it is essential that every research campus have core offerings at the graduate level. Charleston with its large population and current, critical emphasis on both retraining a large naval work force and environmental issues, has no graduate offerings at the master's level, although the funding, faculty, and facilities are in place. Every effort is being made to utilize expertise on other S. C. campuses. Consideration will be given towards using the SCETV Digital Satellite System to make effective use of the state's faculty. However, the interaction of the faculty with the students is critical. Many faculty appropriate for this program are scientists for whom it is essential to be in proximity to their research laboratories. We are, however, giving every consideration to new methods of curriculum development and delivery. One potential outgrowth of such interactions is the development of major program projects in the Environmental disciplines. Thus, by recognizing the strengths of each institution, the state could put forward strong proposals to the federal funding agencies in such areas.

Other South Carolina colleges and universities offer an array of courses of relevance to the environment. We see this proposed program as a model program spearheading environmental education in the state of South Carolina. We see it as a necessary and almost overdue effort attacking problems in the environment that have not received sufficient attention in the past. We suggest a core curriculum which could be implemented at other institutions, augmented by electives that build on MUSC's and UCSC's demonstrated strengths.

\section{E. Needs Assessment}

\section{Introduction}

There will be a critical shortage of professionals who are educated to deal with environmental problems by 1997. This was the major finding of a 1992 study conducted by the Oak Ridge Associated Universities, Incorporated and the Pacific Northwest Laboratory (Publication Number PAL- 8171, CU-700). The study was done to determine the manpower needs of the Office of Environmental Restoration and Waste Management in the US Department of Energy (DOE). Although the focus of the study was the 19 sites of the DOE complex, including the Savannah River Site in South Carolina, the study documented that such shortages will affect other major agencies and organizations including the US 
Department of Interior, the US Department of Defense, the Environmental Protection Agency, state and local governmental agencies, private agencies, and manufacturing enterprises throughout the State of South Carolina and the Nation. The Oak Ridge Study also documented that a variety of professional positions requiring environmental expertise are difficult to fill because traditional educational programs in physical science, engineering, health science, public policy, and administration have not adequately responded to the unique nature of these emerging specialties. This lack of educational preparation has necessitated extensive on-site training of new employees before they can become productive members of the environmental work force. Unique educational initiatives such as the Environmental Studies program proposed here are vital to address the long-term demand for environmental professionals.

\section{Prospective Student Pool}

The interdisciplinary nature of the Environmental Studies program proposed by MUSC and UCSC will attract applicants with baccalaureate degrees in the health sciences, physical sciences, biological sciences, engineering, education, and public policy. Employment opportunities for new graduates and job advancement for professionals employed in environmental occupations will be key factors in attracting qualified applicants. To be a graduate of a formal educational program specific to environmental science and policy will give graduates a competitive advantage when seeking employment since such education is rare.

There are approximately 1,100 baccalaureate degrees in science and engineering awarded annually in the State of South Carolina (Statistical Abstracts, SC Commission on Higher Education, Edition 14). In the Charleston area, the College of Charleston and The Citadel annually award approximately 245 baccalaureate degrees in these disciplines. Projected population increases, combined with state and national efforts directed at increasing science and mathematics competency in schools, will result in projected increases of $15 \%$ $20 \%$ of the science and engineering degrees by the year 2000 . Graduates with these degrees will form a pool of prospective applicants to the Environmental Science program.

The desire for graduate education among employees of area businesses was documented in the 1989 study conducted by the Charleston Higher Education Consortium. Of 3200 employees responding to the survey, $33 \%$ indicated an interest in pursuing a higher degree.

Public and private school teachers, especially those who teach mathematics and biological and physical sciences, form a second applicant pool. Currently, approximately two-thirds of the about 205 Science/Math teachers high school teachers in Berkeley, Charleston, and Dorchester counties do not hold a Master's degree, and most of the earned Master's degree are in education. There are limited Master's degree options locally for degrees in the biological or 
physical sciences. At the same time, there is every indication that the science of the next decades will strongly emphasize environmental issues and that K-12 students will expect from their teachers substantive knowledge in this area. It is, therefore, to be anticipated that the Environmental Studies program will be an attractive option for science teachers who do not possess graduate degrees.

According to the 1989 Charleston Higher Education Consortium survey, approximately $67 \%$ of teachers with baccalaureate degrees would pursue graduate education if programs were available locally and if classes were offered primarily during evening hours. This is understandable because the graduate degree would promise personal reward in terms of promotions and salary increases. It would also provide greater job flexibility for the individual, given the increased demand for teachers with expertise in the environmental arena. Even a very conservative interpretation of this survey implies that a considerable number of teachers would constitute this second applicant pool.

Most of the science teachers would actually meet the admission requirements of the proposed program, but it is recognized that some applicant teachers may have deficiencies even if they are science-certified. It is noted that all course prerequisites can be satisfied locally through the College of Charleston or other institutions of higher education. Every effort will be made to assist qualified applicants in their preparation for entering the program. In addition, a proviso is included in the admission procedure allowing exceptions to be made on a case by case basis depending on a candidate's background or experience.

Graduate education in Environmental Studies would provide an extraordinary opportunity for SC to increase substantially the scientific competency of teachers, which is congruent with the national mandate. Additionally, the students of such teachers would develop an awareness of environmental issues and an interest in pursuing careers focused on these concerns, thus naturally initializing the "K-12 pipeline" toward higher education in Environmental Studies.

We will work closely with the school systems as part of our recruitment effort to assure that all science/mathematics teachers are fully informed about this new graduate education opportunity and its benefits to their career development.

A third pool of prospective students consists of professionals currently employed in agencies and organizations with an environmental facet. In a survey conducted in Fall, 1992, the following organizations indicated an interest in having some of their employees participate in an Environmental Science educational program: The Army Corps of Engineers, SC Coastal Council, SC Marine Resources, SC Ports Authority, the Charleston Aquarium, and the Charleston Soil and Water Conservation District. The co:nbined response of these agencies documented that approximately 30-35 employees would 
participate annually in the proposed graduate program, either as degree candidates or as part-time non-matriculated students.

Finally, while this proposal has been in a stage of preparation and under consideration, we have had over 200 inquiries without any information being released. The need in the Charleston area alone is overwhelming, and the needs of the citizens of this major population area are not being met.

\section{Employment Opportunities for Graduates}

Projections for employment in both the short-term (5-10 years) and the longterm (10-15 years) show an increased demand for individuals with graduate degrees in areas with an environmental specialization, including scientific, engineering, and management areas. Representatives of the Army Corps of Engineers, SC Coastal Council, SC Marine Resources, SC Ports Authority, the Charleston Aquarium, and the Charleston Soil and Water Conservation District have indicated that graduates of the MUSC/UCSC Environmental Studies program would be strongly and uniquely qualified to fill a variety of positions requiring environmental expertise. These ag cicies indicated that they would offer a combined total of 8-12 new positions annually in the Charleston area for individuals with graduate degrees in environmental studies.

Graduates of the program will also have excellent employment opportunity in the Savannah River Site and through out the State of South Carolina as discussed in the following paragraphs.

The South Carolina Employment Security Commission, through its Labor Market Division, provides long-term employment projections by occupation. Table 1 presents projected employment growth in South Carolina for positions for which the graduates of the MUSC/UCSC Environmental Studies Program would be qualified. These projections indicate an average of $611 \mathrm{new}$ positions annually, through the year 2000 . In addition to these positions, other employment opportunities exist in education and public policy agencies both in South Carolina and nationally. Individuals who have advanced degrees and preparation in environmental specialties will have a competitive advantage in these job markets. 
Table 2: MANPOWER NEED PROJECTIONS FOR 1997

In Environmental Restoration and Waste Management

of the Department of Energy (Selected Occupations Only)

\begin{tabular}{lccc}
\hline OCCUPATION & CURRENT & GROWTH & ANTICIPATED \\
& ETE & ETE & ETE \\
Environmental Engineers & 288 & 515 & 803 \\
Environmental Scientists & 100 & 200 & 300 \\
Waste Management Engineers & 77 & 214 & 291 \\
Health Physicists & 70 & 102 & 172 \\
Risk Assessment Managers & 36 & 50 & 86 \\
Biologists & 22 & 45 & 67 \\
Statisticians/Mathematicians & 29 & 34 & 63 \\
Chemists & 112 & 371 & 483 \\
Operations Research Specialists & 7 & 7 & 14 \\
Hydrogeologists & 67 & 132 & 199 \\
Geologists & 29 & 191 & 220 \\
TOTAL & 837 & 1861 & 2698 \\
\end{tabular}

Note: These figures, which are extracted from Table 3.5 of the DOE document No. PNL-8171/UC700 , represent occupations requiring B.S. and advanced degrees for which the graduates of the proposed Environmental Studies program would qualify.)

The Occupational Outlook Handbook published by the US Department of Labor and Bureau of Labor Statistics, 1992 Edition, provides projections for employment and salary data as presented in Table 3. This table contains selected representative occupations for which graduates of the Environmental Studies Program would be prepared and would possess a competitive advantage due to the unique interdisciplinary nature of the proposed program. 


\section{Table 1: EMPLOYMENT PROJECTIONS}

\section{For Selected Occupations in the State of South Carolina}

\begin{tabular}{|c|c|c|c|c|c|c|}
\hline Occupation & $\begin{array}{l}\text { Estimated } \\
\text { oyment }\end{array}$ & $\begin{array}{l}2000 \text { Estimated } \\
\text { Employment }\end{array}$ & $\begin{array}{l}\text { Percent } \\
\text { Change }\end{array}$ & Growth & $\begin{array}{l}\text { Annual } \\
\text { Separations }\end{array}$ & Openings \\
\hline \multicolumn{6}{|l|}{ Selected Engineers } & \\
\hline Chemical & 1,573 & 1,955 & +24.3 & 38 & 37 & 75 \\
\hline Civil & 3,693 & 4,529 & +22.6 & 84 & 79 & 163 \\
\hline Safety & 365 & 449 & +23.0 & 8 & 8 & 16 \\
\hline Marine & 195 & 284 & +45.6 & 9 & 5 & 14 \\
\hline \multicolumn{7}{|l|}{ Scientists: } \\
\hline Chemists & 1,335 & 1,630 & +22.1 & 30 & 42 & 72 \\
\hline Geoscientists & 281 & 355 & +26.3 & 7 & 9 & 16 \\
\hline Conservationists & 218 & 213 & -2.3 & -1 & 7 & 6 \\
\hline Biologists & 502 & 595 & +18.5 & 9 & 16 & 25 \\
\hline \multicolumn{7}{|l|}{ Systems / } \\
\hline Computers/'Math & 3,354 & 4,789 & 42.8 & 144 & 22 & 166 \\
\hline \multicolumn{6}{|l|}{ Inspectors/Compliance } & 15 \\
\hline Officers & 1,479 & 1,689 & +14.2 & 21 & 22 & 43 \\
\hline TOTALS & 13,204 & 16,828 & +27.5 & 362 & 249 & 611 \\
\hline
\end{tabular}

Source: 1992 Report of the Employment Security Commission

The manpower assessment study cited projects a minimum increase of $45 \%$ over the present work force during the next 5 years. This increase in manpower requirements is for the $19 \mathrm{DOE}$ sites and its contractor-operated facilities. The Savannah River Plant in SC, together with its major contractoroperated facilities (Bechtel SR Company, Westinghouse SR Company, US Forest Service at Savannah River, Wackenhut Service, and the University of Georgia) are regarded as a major DOE site. Table 2 presents the projected manpower needs for selected occupations for which the graduates of the Environmental Studies Program would be qualified at the DOE sites. Depending upon the area of specialization, approximately $25 \%-35 \%$ of the anticipated manpower will be at the Savannah River Site. 
Table 3: JOBS AND SALARY EXPECTATIONS

Projected Growth Within the Time Frame: 1990-2005

\begin{tabular}{lcc}
\hline OCCUPATION & $\begin{array}{c}\text { PROJECTED } \\
\text { GROWTH }\end{array}$ & $\begin{array}{c}\text { 1992 AVERAGE } \\
\text { STARTING SALARIES } \\
\text { WITH MASTERS }\end{array}$ \\
Biological Sciences & $25-34 \%$ & $\$ 26,800$ \\
Geologists & $14-24 \%$ & 26,500 \\
Operations Research Analyst & $35 \%+$ & $30-35,000$ \\
Statisticians/Mathematicians & $5-13 \%$ & $32-36,000$ \\
Civil \& Environmental Engineers & $25-34 \%$ & 32,000 \\
Inspectors \& Compliance Officers & $25-34 \%$ & 29,500 \\
\hline
\end{tabular}

Many national surveys state the need for students with graduate education in environmental studies. Science recently had an editorial on this issue. Clemson has informed us that every student receiving a graduate degree from their environmental engineering and toxicology programs receives at least four job offers.

In summary, the Environmental Studies Program proposed by the Medical University of South Carolina and the University of Charleston is expected to draw upon a rich pool of potential applicants from graduates of local and state-wide baccalaureate programs and from individuals already employed in education or environmentally related occupations. Employment opportunities for graduates of the Environmental Studies Program will be plentiful due to the regional location of many government agencies and private organizations and businesses with needs for professional personnel with environmental expertise. The graduates of this program will have a competitive advantage due to the interdisciplinary and collaborative structure of the program in an emerging discipline where few formal educational programs exist today.

\section{ENROLLMENT}

\section{A. Anticipated Enrollment}

Our assessment of enrollment in the Master's program in Environmental Studies is largely based on the needs analysis provided in Section II. E. It also takes into account a period of five years during which the enrollment numbers will gradually increase to the anticipated steady-state of approximately 100 students (headcount). Of these we expect an average of about $25 \%$ non- 
traditional students carrying a smaller course load of six credit hours per semester. This course load affects the total student FTE count as shown in Table 4.

The anticipated enrollment numbers are expected to be considerably lower than the numbers of applications. This will allow us to be selective in admission, thus insuring high academic standards for admission and graduation.

Table 4: PROJECTED ENROLLMENT

in Environmental Studies (Headcount)

\begin{tabular}{|c|c|c|c|c|c|}
\hline & 1994-95 & 1995-96 & 1996-97 & $1997-98$ & $1998-99$ \\
\hline $\begin{array}{l}\text { Student } \\
\text { Headcount }\end{array}$ & 20 & 40 & 70 & 90 & 100 \\
\hline Student FTE & 17.5 & 35 & 61.25 & 78.75 & 87.5 \\
\hline
\end{tabular}

\section{B. Discussion of Estimates}

The basis of our enrollment projections comes from a number of areas identified in our needs assessment (see Section II.E: Needs Assessment above) as well as general inquiries received from the public at both institutions. Our projections are made on a number of assumptions. We assume that the average student will complete the degree within 2.5 years and that $25 \%$ of the students will be nontraditional, i.e., carrying six credit hours per semester and taking longer than two years to complete the program. After five years we project that 100 students will be in our program (= 100 headcount; Table 4$)$. This would require that 40 students enter the program each year (100 students $/ 2.5$ years). From our needs assessment, we anticipate that a number of groups will have a particular interest in the program, including the following:

1) public or private school teachers (5)

2) professionals employed with agencies and organizations with environmental concerns (e.g., Army Corps of Engineers, SC Coastal Council, SC Marine Resources, SC Ports Authority, the Charleston Aquarium, the Charleston Soil and Water Conservation District, the National Marine Fisheries Service laboratory) (17) 
3) local industry and businesses (10)

4) students interested in the hard sciences (8)

\section{Estimated Credit Hours}

Based on our projections in the previous Section III. B, one readily estimates the number of credit hours earned by students per year. For instance, 75 traditional and 25 non-traditional students in the academic year 1998-99 correspond to 87.5 Student FTE's. Given a normal course load of 12 credit hours per Fall or Spring semester and 6 credit hours in the Summer semester, the estimated credit hours earned by students in the academic year $1998-99$ are $87.5 \times 12=1,050$ or $87.5 \times 6=525$, respectively. These estimates are summarized in Table 5.

Table 5: ESTIMATED CREDIT HOURS

Earned by Students

\begin{tabular}{lccc}
\hline Year & Fall & Spring & Summer \\
\hline $1994-95$ & 210 & 210 & 105 \\
$1995-96$ & 420 & 420 & 210 \\
$1996-97$ & 735 & 735 & 368 \\
$1997-98$ & 945 & 945 & 473 \\
$1998-99$ & 1050 & 1050 & 525 \\
\hline
\end{tabular}

\section{Admission}

General admission requirements are in accordance with University, College, and Departmental guidelines. They include GRE scores and a TOEFL score, where applicable. Students with a background in the natural sciences, mathematics, or engineering, as well as non-traditional students are especially encouraged to apply. Ultimately decisions on admission rest with the graduate deans of the Medical University of South Carolina and the University of Charleston, South Carolina.

\section{Minimum Standards for Admission}


Entering students are expected to have completed significant coursework in one or several areas of science or mathematics. In particular, they should satisfy course prerequisites, as outlined below. Students who do not satisfy some of these course prerequisites, but otherwise seem well-suited for the program, may be admitted but must remedy deficiencies during their tenure in the program.

These are the minimum prerequisites for all three programs of study. Some programs may elect to require additional course prerequisites for admission.

2. Specific admission requirements

Mathematics: One year of college-level mathematics

Science:

Two courses in biology, plus accompanying laboratories

Two courses in chemistry, plus accompanying laboratories

Statistics

One senior undergraduate or graduate level course in statistics

These are the minimum prerequisites for all three programs of study. Admission to the Environmental Science track requires an undergraduate degree in one of the basic scientific and engineering disciplines. It is recognized that some applicants may not satisfy all requirements. Every effort will be made to accommodate qualified applicants through preparatory classes at the College of Charleston. Furthermore, exceptions can be made on a case by case basis depending on a candidate's background or experience.

\section{CURRICULUM}

\section{A. General Discussion}

We submit that one of the great strengths of this program is the commingling of the study of science and policy. The program is of sufficient scientific rigor that students with a specific interest in using the Master's degree in Environmental Studies to practice science and/or pursue a doctoral degree may easily do so. We suggest that the broad scope of the curriculum, and especially the background the student obtains in policy, will enable the student to understand better how science and policy must interact, with the emphasis being on risk to human health. 
The program is also designed to serve the student whose primary interests may be in areas other than science, e.g., a political science major, but who has some science background. Coursework in the core curriculum will provide the student with a broad foundation in the basic sciences such that the student has a clear understanding of what science is, what it can do, what it cannot do, and how scientists think and work.

All students will have significant coursework in the policy area and this, perhaps more than anything else, distinguishes this program from other environmental programs. The first core course, the Public Policy Process, is designed to give students a comprehensive overview of policy making as well as general theoretical frameworks within which the process may be understood. Environmental policy is best understood in the context of public policy in general. Environmental policy proposals get placed on the policy docket just as any others do and are subject to the same general institutional processes and pressures as they wind their way through the system.

Theoretical frameworks for understanding the policy process are crucial to allow students to see what forces are at work in the formulation of public policy. Many see policy as elitist in nature; that is, as fundamentally shaped by a narrow ruling minority. Many see it as pluralist; that is, as an open process in which different and divergent groups can participate. Between these two perspectives lies a range of other interpretations that will aid students in understanding how environmental policy is finally developed.

Another crucial area of understanding public policy is in implementation studies. The implementation of public policy is often an area where procedural breakdowns occur. In essence, it is the realm in which ideas get translated into practice, often to the frustration of those who formulated the policy.

The fundamental debate about public policy over the last three decades has focused on how the process should occur. The second core policy course, the Economic Theory for Policy Analysis course, provides students with the tools for understanding this debate as well as tools for policy analysis. Policy analysis in the form of cost/benefit or cost/effectiveness studies or other rational schemes is not scientific research. Public policy decisions must constantly weigh between overall competing interests. In the case of environmental policy, these competing interests have primarily been economic in nature--short-term jobs and economic well-being as opposed to longer-term health or resource interests. In understanding these dimensions of political economy, students will have a real grasp of environmental issues.

We believe that one of the most effective ways of establishing the link between the practice of science and the practice of policy making is through the study of specific cases. Case studies also impart a unique opportunity to explore basic principles of biology, chemistry, geology, and physics through practical 
applications. Therefore, we have created a Case Studies in Environmental Science course that investigates specific case studies. This approach to problems will indeed be similar to that used by the practitioners of science and public policy.

Finally, students will have an opportunity to integrate their knowledge of policy and science toward the end of their studies through the Capstone Seminar. In this setting, a small group of students will be provided with a particular environmental scenario, e.g., an oil spill, where they will be required to investigate the underlying scientific and policy principles in formulating a formal course of action that might be taken. The Capstone Seminar is intended to allow the students with different strengths and interests to work together to formulate a plan that can responsibly address the particular scenario they have been assigned. This approach is intended to simulate the situations the students will likely encounter in "real world" scenarios.

\section{B. Staffing of Courses}

The core courses will be staffed approximately as follows:

\begin{tabular}{|c|c|c|c|}
\hline COURSE & EACULTY MEMBER & DEPARTMENT & $\mathrm{SCHOOL}$ \\
\hline \multirow[t]{2}{*}{ Risk Assessment } & David Hoel & $\begin{array}{l}\text { Biometry \& } \\
\text { Epidemiology }\end{array}$ & MUSC \\
\hline & Eberhard Voit & $\begin{array}{l}\text { Biometry \& } \\
\text { Epidemiology }\end{array}$ & MUSC \\
\hline Environmental Biology & $\begin{array}{l}\text { Louis Burnett } \\
\text { David Jollow } \\
\text { David McMillan } \\
\text { JoEllyn McMillan } \\
\text { Susan Morrison } \\
\text { Michael Schmidt }\end{array}$ & $\begin{array}{l}\text { Biology } \\
\text { Pharmacology } \\
\text { Pharmacology } \\
\text { Pharmacology } \\
\text { Biology } \\
\text { Microbiology \& } \\
\text { Immunology }\end{array}$ & $\begin{array}{l}\text { UCSC } \\
\text { MUSC } \\
\text { MUSC } \\
\text { MUSC } \\
\text { UCSC } \\
\text { MUSC }\end{array}$ \\
\hline Earth Systems Science & $\begin{array}{l}\text { Mitchell Colgan } \\
\text { Phillip Dustan }\end{array}$ & $\begin{array}{l}\text { Geology } \\
\text { Biology }\end{array}$ & $\begin{array}{l}\text { UCSC } \\
\text { UCSC }\end{array}$ \\
\hline \multirow{2}{*}{$\begin{array}{l}\text { Energy Production \& Resource } \\
\text { Management }\end{array}$} & Robert Dukes & Physics & UCSC \\
\hline & Jeff Wragg & Physics & UCSC \\
\hline Environmental Chemistry & Frank Kinard & Chemistry & UCSC \\
\hline
\end{tabular}


COURSE

Public Policy Process

Economic Theory for Policy Analysis

Case Studies in Environmental

Sciences

Capstone Seminar

\begin{tabular}{|c|c|c|}
\hline $\begin{array}{l}\text { EACULTYMEMBER } \\
\text { Andy Felts } \\
\text { Faculty to be Hired }\end{array}$ & $\begin{array}{l}\text { DEPARTMENT } \\
\text { Political Science }\end{array}$ & $\frac{\text { SCHOOL }}{\text { UCSC }}$ \\
\hline Faculty to be Hired & & UCSC/MUSC \\
\hline Karen Burnett & $\begin{array}{l}\text { Microbiology \& } \\
\text { Immunology }\end{array}$ & MUSC \\
\hline Louis Bumett & Biology & UCSC \\
\hline Mitchell Colgan & Geology & UCSC \\
\hline Phillip Dustan & Biology & UCSC \\
\hline Arthur Felts & Political Science & UCSC \\
\hline David Hoel & $\begin{array}{l}\text { Biometry \& } \\
\text { Epidemiology }\end{array}$ & MUSC \\
\hline David Jollow & Pharmacology & MUSC \\
\hline Michael Katuna & Geology & UCSC \\
\hline Frank Kinard & Chemistry & UCSC \\
\hline David McMillan & Pharmacology & MUSC \\
\hline JoEllyn McMillan & Pharmacology & MUSC \\
\hline Susan Morrison & Biology & UCSC \\
\hline Robert Nusbaum & Geology & UCSC \\
\hline Michael Reed & Env. Health & MUSC \\
\hline Michael Schmidt & $\begin{array}{l}\text { Microbiology \& } \\
\text { Immunology }\end{array}$ & MUSC \\
\hline Jeff Wragg & Physics & UCSC \\
\hline Various Facul & & MUSC/ \\
\hline
\end{tabular}

Depending on the expertise of faculty to be hired, Drs. Jollow and J. McMillan (MUSC: Pharmacology), Dr. Meier (MUSC: Pharmaceutical Sciences), and Dr. Schmidt (MUSC: Microbiology and Immunology) may be assigned to teach sections of the elective courses Environmental Toxicology and Microbiology and Environmental Toxicology. Drs. Miller and Zhang (Biometry \& Epidemiology) may be assigned to teach Operations Research and Decision Making, and Dr. Dunbar (Biometry \& Epidemiology) may be assigned to teach Environmental Epidemiology.

Other existing elective courses will be taught by the current course instructors. The new elective courses will be taught by existing or new faculty. In cases where existing faculty are reassigned to these courses, new faculty will be hired for FTE replacement, according to Section V.E.

The distribution of proposed courses between the institutions is shown in Section IV.D.

\section{Degree Requirements}


In accord with the emphasis of both institutions to educate traditional students as well as non-traditional students who may have learning and career goals in a diversity of areas, the program offers maximal flexibility for completion of the student's program of study. The degree requires 38 credit hours with the exception of the track in Environmental Science which requires an additional elective course for a total of 41 or 42 credit hours. Every student is required to complete the same set of core courses and adds additional electives, according to his or her area of specific interest. Science electives may be taken at Clemson University or the University of South Carolina, to be decided possibly on a case by case basis.

The core courses fall into three categories: Science, Policy, and Interdisciplinary. There will be a strong emphasis on human health risk issues.

\title{
Core Courses
}

(XX numbers indicate proposed courses)

\section{Science:}

BIOM/EPID 780 (MUSC)

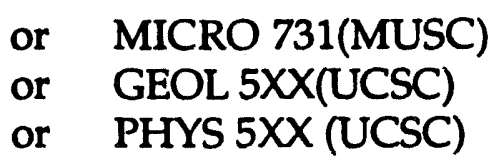

or CHEM 522, 522L (UCSC)
Environmental Health Risk Assessment-(4)

Environmental Biology-(4)

Earth Systems Science-(4)

Energy Production \& Resource Management-(4)

Environmental Chemistry-(4)

Policy:

PUBA-602 (UCSC)

PUBA-706 (UCSC)
Public Policy Process-(3)

Economic Theory for Policy Analysis-(3)

Interdisciplinary:

ENVI 6XX (MUSC, UCSC)

ENVI 7XX (MUSC, UCSC)

\author{
Case Studies in Environmental \\ Science- (4) \\ Capstone Seminar-(2)
}

TOTAL: 20 credit hours

In addition to these twenty credit hours for the core, every student selects, with the advice of his or her Advisory Committee, 18-22 further credit hours. Twelve to sixteen of these are earned by completion of courses. The remaining six may be devoted to either the completion of a thesis; an internship (documented by a 
technical report); library research (documented by a report); or further course electives.

\section{Other Requirements}

Before a student is admitted to core courses in the Interdisciplinary category, he or she must satisfactorily pass a comprehensive examination, covering course material of the Science and Policy core courses. Human health risk assessment will be a central theme of this program.

Track in Risk Assessment

$\begin{array}{lc}\begin{array}{l}\text { Core Courses } \\ \text { BIOM/EPID -736 }\end{array} & \begin{array}{l}20 \text { credit hours } \\ \text { BIOM/EPID -750 }\end{array} \\ \begin{array}{l}\text { Introduction to Biomedical } \\ \text { Systems Analysis-(3) }\end{array} \\ \begin{array}{l}\text { One course from List A } \\ \text { One course from List A, B, } \\ \text { C, or D }\end{array} & 3 \text { credit hours } \\ \begin{array}{l}\text { Thesis, Internship, Library } \\ \text { Research, or Course Electives }\end{array} & 3 \text { credit hours } \\ \text { TOTAL } & 6 \text { credit hours }\end{array}$

Track in Environmental Policy

Core Courses

20 credit hours

Three courses from:

PUBA 502B, 502D,

$502 \mathrm{P}, 606,622,631$,

633

9 credit hours

One course from

List $A, B, C$, or D

3 credit hours

Thesis, Internship, Library

Research and/or Course

Electives, or Course Electives 6 credit hours

TOTAL

38 credit hours

Track in Environmental Science 
Students will choose an area of concentration in Biology, Chemistry, Geology, or Physics.

Core Courses

Electives

Thesis or Internship

TOTAL
20 credit hours

To be determined by each concentration

(15-16 credit hours)

6 credit hours

41-42 credit hours

\title{
List A
}

\author{
Statistics \\ BIOM/EPID 702 Introduction to Experimental \\ Design-(3) \\ BIOM/EPID 710 Regression Methods in Biology and Medicine-(3) \\ BIOM/EPID 711 Analysis of Categorical Data-(3) \\ BIOM/EPID 712 Sampling Methods in Biology and Medicine-(3) \\ Epidemiology \\ BIOM/EPID 736 Epidemiological Foundations-(3) \\ BIOM/EPID 738 Advanced Epidemiology: Design and Conduct of \\ Epidemiological Studies-(3) \\ BIOM/EPID 7XX Environmental Epidemiology \\ BIOM/EPID 7XX Exposure Analysis \\ BIOM/EPID 737 Epidemiology of Cardiovascular Disease \\ Systems Science \\ BIOM/EPID 742 \\ BIOM/EPID 750 \\ BIOM/EPID 754 \\ Computer Systems and Languages-(3) \\ BIOM/EPID 762 \\ Introduction to Biomedical Systems Analysis-(3) \\ BIOM/EPID 7XX \\ Nonlinear Systems Analysis-(3) \\ BIOM/EPID 7XX \\ Modeling and Simulation-(3) \\ Operations Research and Decision Making \\ Transport Processes of Environmental Toxicants
}


List $B$

Basic Science Departments (MUSC)

53-745 Pharmacokinetics-(3)

30-622 General Microbiology-(5)

12-725 Specialized Toxicology Courses

051-621 Pharmacology-(4)

11-502G Core Biochemistry-(9)

51-734 Drug-Receptor Interactions

51-736 Drug Metabolism and Pharmacokinetics

51-745 Pharmacokinetics I-(3)

30-773 Pollution Microbiology-(3)

30-774 Pollution Microbiology - Lab-(3)

30-772 Environmental Microbiology-(4)

30-732 Techniques in Immunology \& Molecular Genetics

51-740 Toxicology

University of Charleston

BIOL 510 Field Methods in Marine Ecology-(2)

BIOL 600 Physiology and Cell Biology of Marine Organisms-(4)

BIOL 601 Population Biology and Ecology of Marine Organisms-(4)

BIOL 610 Physical Oceanography-(4)

BIOL 611 Biometry-(4)

BIOL 640 Applied and Environmental Microbiology-(4)

BIOL 642 Aquatic Toxicology-(4)

BIOL 643 Fisheries Science-(3)

BIOL 644 Aquaculture-(3)

CHEM 522 Environmental Chemistry-(3)

CHEM 522L Environmental Chemical Laboratory-(1)

CHEM 524 Environmental Analytical Chemistry-(3)

CHEM 526 Introduction to Nuclear and Radiochemistry-(1)

CHEM 528 Nuclear and Radiochemistry-(3)

GEOL 5XX Aqueous Geochemistry-(4)

GEOL 5XX Earth Systems Science-(4)

GEOL 6XX Coastal Processes and Issues-(3)

GEOL 6XX Environmental Geochemistry-(3)

GEOL 6XX Modeling Earth Systems-(3)

PHYS 5XX Introduction to Nuclear Physics-(4)

PHYS 5XX Energy Production and Resource Management-(3)

PHYS 6XX Digital Image Processing-(3)

PHYS 6XX Atmospheric Science-(4)

PHYS 6XX Climatology-(4) 
List C

Policy

PUBA-502B Politics of Governmental Regulation-(3)

PUBA-502D Coastal Resource Management-(3)

PUBA-502P Environmental Politics-(3)

PUBA-510 Computers in Government

PUBA-600 Perspectives on Public Administration-(3)

PUBA 605 Financial Administration-(3)

PUBA-608 Accountability and Administrative Ethics-(3)

PUBA 611 Urban Public Policy-(3)

PUBA-622 Intergovernmental Relations-(3)

PUBA-631 Administrative Law-(3)

PUBA-663 Policy Evaluation-(3)

PUBA-712 Organizational Behavior-(3)

PUBA-722 Information Systems and Public Administration-(3)

MUSC 7XX Health Policy

\section{List D}

Department of Environmental Health Sciences - (to be developed)

EHSXXX Concepts in Environmental Engineering-(3)

EHSXXX Management of Hazardous Waste Sites-(3)

EHSXXX Industrial Hygiene-(3)

EHSXXX Health Physics-(3)

EHSXXX Environmental Management-(3)

\section{Sample Curriculum}

First Semester: Environmental Biology (4 credit hours) and Public Policy Process ( 3 credit hours). In addition, electives from the student's major area of interest. This first semester also provides the opportunity to remedy deficiencies, e.g., in statistics.

Second Semester: Environmental Health Risk Assessment (4 credit hours), Economic Theory for Policy Analysis ( 3 credit hours), and further electives. After the second semester (during the summer) the student participates in an externship of about 2 or 3 months. 
Third Semester: The core of this semester is the Case Studies in Environmental Science course ( 4 credit hours). The remaining credit hours are used for electives and thesis work, if applicable.

Fourth Semester: Capstone Seminar ( 2 credit hours), further electives, and completion of thesis, if applicable.

Sample Plan of Study A: Student with B.S. in Biology and interest in environmental science- biology concentration and thesis option.

First Semester: Science Core outside of Biology (Environmental Chemistry and Lab-4)

Policy Core (Public Policy Process-3)

Elective (Applied and Environmental Microbiology-4)

Introduction to Biostatistics-4 (Remediation)

(11 credit hours + Remediation)

Second Semester. Science Core (Environmental Health Risk Assessment-4)

Policy Core (Economic Theory for Policy Analysis-3)

Elective (Aquatic Toxicology-4)

(11 credit hours)

Summer I: $\quad$ Thesis work-3

( 3 credit hours)

Third Semester: Interdisciplinary Core (Case Studies in Environmental Science-4)

Elective (Fundamentals of Systems Science-3)

(7 credit hours)

Fourth Semester: Interdisciplinary Core (Capstone Seminar-2)

Elective (Environmental Epidemiology-3)

( 5 credit hours)

Summer II: Thesis work -4

( 4 credit hours)

Total Number of Credit Hours: 41 
Sample Plan of Study B: Student with B.S. in Mathematics and interest in environmental modeling

First Semester: Science Core (Environmental Biology -4)

Policy Core (Public Policy Process-3)

Elective (Fundamentals of Epidemiology-3)

(10 credit hours)

Second Semester: Science Core (Environmental Health Risk Assessment-4)

Policy Core (Economic Theory for Policy Analysis-3)

Elective (Modeling and Simulation-3)

(10 credit hours)

Summer I: $\quad$ 12-week internship with Risk Assessment Group at Westinghouse Savannah River Site, Aiken, SC.

Third Semester: Interdisciplinary Core (Case Studies in Environmental Science-4)

Elective (Systems Analysis II - Nonlinear Systems-3)

Elective (Pharmacokinetics-3)

(10 credit hours)

Fourth Semester: Interdisciplinary Core (Capstone Seminar-2)

Elective (Operations Research-3)

Elective (Transport Processes of Environmental Toxicants-3)

Elective (Concepts of Environmental Engineering-3)

(11 credit hours)

Total number of credit hours: $41+$ Internship

(Note: Fundamentals of Systems Science waived because of student's mathematics background) 
Sample Plan of Study C: Student with B.S. in Chemistry and interest in environmental chemistry.

First Semester: Science Core (Environmental Biology-4)

Policy Core (Public Policy Process-3)

Elective (Environmental Chemistry-4)

(11 credit hours)

Second Semester: Science Core (Environmental Health Risk Assessment-4)

Policy Core (Economic Theory and Policy Analysis-3)

Elective (Environmental Analytical Chemistry-3)

(10 credit hours)

Summer I: $\quad$ Thesis work-3

( 3 credit hours)

Third Semester: Interdisciplinary Core (Case Studies in Environmental Science-4)

Elective (Nuclear and Radiochemistry-3)

Elective (Energy Production and Resource Management-3)

(10 credit hours)

Fourth Semester: Interdisciplinary Core (Capstone Seminar-2)

Elective (Special Topics in Environmental Chemistry-3)

(5 credit hours)

Summer II: $\quad$ Thesis work-3

( 3 credit hours)

Total Number of Credit Hours-42 
Sample Plan of Study D: Student with B.S. in Geology and interest in environmental science.

First Semester: Science Core (Environmental Biology-4)

Policy Core (Public Policy Process-3)

Elective (Aqueous Geochemistry-4)

(11 credit hours)

Second Semester: Science Core (Environmental Health Risk Assessment-4)

Policy Core (Economic Theory and Policy Analysis-3)

Elective (Environmental Geochemistry-3)

Elective (Modeling Earth Systems-3)

(13 credit hours)

Summer I: $\quad$ Thesis work-3

( 3 credit hours)

Third Semester: Interdisciplinary Core (Case Studies in Environmental Science-4)

Elective (Coastal Processes and Issues-3)

(7 credit hours)

Fourth Semester: Interdisciplinary Core (Capstone Seminar-2)

Elective (Satellite Remote Sensing-3)

(5 credit hours)

Summer II: Thesis work-3

( 3 credit hours)

Total Number of Credit Hours -42 
Sample Plan of Study E: Student with B.S. in physics and interest in environmental science.

First Semester: $\quad$ Science Core (Environmental Biology-4)

Policy Core (Public Policy Process-3)

Elective (The Physics of Energy Production-3)

(10 credit hours)

Second Semester: Science Core (Environmental Health Risk Assessment-4)

Policy Core (Economic Theory and Policy Analysis-3)

Elective (Atmospheric Science-4)

(11 credit hours)

Summer I: $\quad$ Thesis work-3

( 3 credit hours)

Third Semester: Interdisciplinary Core (Case Studies in Environmental Science-4)

Elective (Digital Image Processing-4)

( 8 credit hours)

Fourth Semester: Interdisciplinary Core (Capstone Seminar-2)

Elective (Climatology-4)

(6 credit hours)

Summer II: $\quad$ Thesis work-3

( 3 credit hours)

Total Number of Credit Hours-41 
Sample Plan of Study F: Student with B.A. in Political Science and interest in environmental policy.

First Semester: Science Core (Earth Systems Science-4)

Policy Core (Public Policy Process-3)

Elective (Perspectives-3)

(10 credit hours)

Second Semester: Science Core (Environmental Health Risk Assessment-4)

Policy Core (Economic Theory and Policy Analysis-3)

Elective (Environmental Politics-3)

(10 credit hours)

Summer I: $\quad$ Internship-6

(6 credit hours)

Third Semester: Interdisciplinary Core (Case Studies in Environmental Science-4)

Elective (Administrative Law-3)

(7 credit hours)

Fourth Semester: Interdisciplinary Core (Capstone Seminar-2)

Elective (Policy Evaluation-3)

(5 credit hours)

Total Number of Credit Hours-38 


\section{E. Courses}

\section{New Courses to be Added}

New courses at UCSC are 500 and 600 level courses. Many of the new courses developed are 700 level courses at MUSC since these courses also serve a number of Ph.D. programs. Students currently in MUSC's Master's programs commonly take 700 level courses.

a. UCSC

\section{Biology}

BIOL 5XX - ENVIRONMENTAL BIOLOGY AND TOXICOLOGY-(4) This course emphasizes the responses of organisms and ecosystems to environmental variables, both natural and man-made. The methodology scientists use to assess these responses will be discussed. The course will also introduce the fundamental concepts of toxicology and how toxic substances affect the physiology, behavior and distribution of organisms.

\section{Geology}

GEOL 5XX- SATELLITE REMOTE SENSING-(3) An analysis of satellite remote sensing systems including Landsat, and airborne radar images, in conjunction with Geographic Information Systems. Application of image enhancement techniques to monitoring and remediation of environmental problems and hazards. Prerequisites: GEOL 201, GEOL 208, GEOL 210, GEOL 306.

GEOL 5XX - AQUEOUS GEOCHEMISTRY-(4) A detailed examination of the chemical processes which affect ground-and-surface waters, especially those which control the migration of common water contaminants. Topics include mass transport, equilibria, chemical retardation, Eh-pH stability, stable isotopes, and geochemical cycles. Lectures 3 hours per week; laboratory, 3 hours per week. Prerequisites: GEOL 101 AND GEOL 102, AND CHEM 111, 112, or permission of the instructor.

GEOL 5XX - EARTH SYSTEMS SCIENCE-(4) This course investigates the interactions among the atmosphere, ocean, ice, solid Earth, and biological systems. Students will study the evolution of solid-Earth, the formation of the atmosphere and oceans, and the origin of life. Rate and scale of changes of the Earth's environment will be examined through an analysis of changing climates. Finally, the course examines human evolution and technological development to gain an understanding of human impacts on the global environment. 
GEOL 6XX-COASTAL PROCESSES AND ISSUES-(3) This course will provide an in-depth understanding of the coastal environment, including coastal polici ss and env .unmental issues that result from the activity of humans. Subjects that will be covered include: origin of coastlines, physical processes, coastal hazards, and coastal zone management. Lectures 3 hours per week. Prerequisites: GEOL 101, 101L, GEOL 102, 102L, GEOL 207, 207L OR GEOL 210, $210 \mathrm{~L}$.

GEOL 6XX- ENVIRONMENTAL GEOCHEMISTRY-(3) A quantitative study of isotopic and organic geochemistry in reference to geological systems. The utility of combining stable isotopic data for pathway processes and radiogenic isotopes as environmental tracers for inorganic and organic compounds will be emphasized. Prerequisites: Aqueous Geochemistry, GEOL 205, GEOL 220, CHEM 231, CHEM 231-L

GEOL 6XX-MODELING EARTH SYSTEMS-(3) A quantitative approach to modeling groundwater systems, rock-fluid interaction in a hydrothermal environment, and global change. Biogeochemical cycles involving carbon, sulfur, nitrogen, and phosphorous will be emphasized, in addition to isotope geochemistry and volcanism. Prerequisites: GEOL 650

\section{Physics}

\section{PHYS - 5XX - ENERGY PRODUCTION AND RESOURCE MANAGEMENT-(4)}

A graduate level course for those with science backgrounds. It will address the issues of energy production, storage, distribution and use from a physics perspective. Production methods to be studied include: Hydroelectric, fossil fuel, fission, fusion, wind, photovoltaic, bio-mass, and solar-dynamic.

PHYS - 5XX - INTRODUCTION TO NUCLEAR PHYSICS -(4) An introduction to the theory of the nucleus including constituents of the nucleus; nuclear forces and structure; natural and induced radioactivity; properties of alpha, radiation with matter, including biological systems; particle accelerators; fission reactions; fusion reactions; and nuclear reactors. Lecture four semester hours with some laboratory exercises included. Prerequisite: one year of physics and calculus or permission of instructor.

PHYS - 6XX - DIGITAL IMAGE PROCESSING -(3) An introduction to the techniques of digital image acquisition and processing. This course will include both lectures on the theory of the subject as well as hands-on work with state-ofthe-art detectors and computer algorithms. Topics to be covered include imaging devices and detectors; image visualization; noise sources in real detectors; image histograms and filtering; image processing in the frequency domain; deconvolution techniques; and relevant applications in the field of remote sensing. Prerequisite: One year of physics and one year of calculus or permission of the instructor. 
PHYS - 6XX - ATMOSPHERIC SCIENCE-(4) An introduction to the study of the Earth's atmosphere. Topics covered include composition and distribution of the components of the atmosphere; atmospheric thermodynamics; synoptic meteorology; atmospheric aerosol; nucleation processes; microphysics of warm and cold clouds; cloud morphology; violent storms; and artificial modification of clouds and precipitation. Lecture four semester hours with some laboratory exercises included. Prerequisites: Physics 307, Math 323 prerequisite (or corequisite) or permission of instructor.

PHYS - 6XX - CLIMATOLOGY-(4) An introduction to the study of the physics of the Earth's climate. Topics include climatic change and classification; the spectrum of radiation; absorption; scattering; transmission; radiation; the tropospheric balance; the energy balance at the Earth's surface; time variations in the energy balance; apparent forces in a rotating coordinate system; the horizontal and vertical equations of motion; the continuity equation; the primitive equations; thermally driven circulations; the atmospheric transport of energy; the atmosphere as a heat engine; the ozone problem. Lecture four semester hours with some laboratory exercises included. Prerequisites: Atmospheric Science or permission of instructor.

\section{b. MUSC}

\section{BIOMETRY \& EPIDEMIOLOGY}

780 PRINCIPLES OF ENVIRONMENTAL HEALTH RISK ASSESSMENT-(3) The course begins with a historical account of risk assessment and risk management. It then introduces statistical and epidemiological concepts, including competing risks, odds ratios, and proportional hazard models. Next it describes hazard and risk identification and the basics of toxicological testing. Mathematical models for toxicologic phenomena and risk-based decision making are outlined. Questions of risk, uncertainty, and causation, as well as the disparities between real and perceived risk are addressed. All concepts are illustrated with actual examples.

7XX ENVIRONMENTAL EPIDEMIOLOGY-(3) This is an introductory course designed to acquaint students with how epidemiology can be used in studies of the influence of the environment on human health in an occupational setting and in the community. The goals of this course are to introduce the student to (a) the sources of data used in health studies; (b) the epidemiologic research designs; (c) the concept of control of biases; (d) evaluation of the environmental, medical and public health literature, and; (e) the environmental additives which may be of public health concern.

7XX EXPOSURE ANALYSIS-(3) This course discusses environmental pathways of toxicants and questions of human exposure. It includes methods of exposure 
estimation for different types of uptake, assessment of daily doses, and the impact of toxicants on human physiology and metabolism. Mathematical models for dose-response relationships, interspecific extrapolation, and pharmacokinetics, as well as questions of safe and virtually safe doses are described in detail.

7XX OPERATIONS RESEARCH AND DECISION MAKING-(3) This course introduces topics in operations research, industrial management, forecasting and decision making relevant to health services system sciences and research. The course is intended for graduate students interested in teaching and research careers in health services administration and research.

7XX TRANSPORT PROCESSES OF ENVIRONMENTAL TOXICANTS-(3) This course offers a graduate level treatment of the transport processes which effect the distribution of pollutants in the environment. The material primarily addresses students in the Department of Biostatistics, Epidemiology, and Systems Science who are interested in mathematical modeling. The course includes transport mechanisms, field equations, and selected modeling techniques. Application will reflect current research topics.

\section{Basic Sciences}

731 ENVIRONMENTAL BIOLOGY - (4) The course emphasizes the application of fundamental toxicological and microbiological concepts to problems which exist in the real world. The course should prepare the student interested in environmental problems with the necessary practical information to make sound judgments in assessing meaningful solutions to existing environmental problems.

740 TOXICOLOGY- (4) The course emphasizes the application of fundamental toxicological concepts to problems which exist in the real world. The course should prepare the student interested in environmental problems with the necessary practical information to make sound judgments in assessing meaningful solutions to existing environmental problems.

773 POLLUTION MICROBIOLOGY -(3) This course is designed to give the student a practical as well as academic introduction to "real world" pollution problems than can be addressed biologically. Biochemical and genetic mechanisms of biodegradation of aromatic and aliphatic compounds, chlorinated compounds, nitroaromatics, and hydrocarbons will be explored with special emphasis placed on the microbial transformations responsible for the degradation. In addition, the microbiology of activated sludge, anaerobic digestion, composting, and other liquid, air, and solid phase waste treatment processes will be developed in this course. 


\section{Department of Environmental Health}

7XX - CONCEPTS IN ENVIRONMENTAL ENGINEERING-(3) This course presents the basic concepts in engineering solutions to environmental issues. The objectives are to expose the student to technological advances in air pollution control technology, water treatment processes, and pretreatment procedures for hazardous waste. New technologies will be explained which are used to reclaim land contaminated with toxic materials.

7XX - MANAGEMENT OF HAZARDOUS WASTE SITES-(3) This course focuses on the requirements necessary for identification of a proper location for a hazardous waste site, design and construction of the necessary facilities to process and store hazardous waste, segregation of hazardous wastes based on actual operating facility. Existing hazardous waste sites designated for remediation will be studied using risk assessment techniques and the appropriate environmental restoration technology selected.

7XX - INDUSTRIAL HYGIENE-(3) This is an introductory course in basic industrial hygiene concepts. The student will achieve a clear understanding of worker protection issues directly associated with occupational safety and health. Physical hazards to include noise, heat stress, cold stress, and ergonomics will be studied. Chemical hazards will focus on health hazards to include carcinogens, reproductive toxins, and specific target organ effects. Radiation hazards will emphasize laser safety and radiofrequency, ultraviolet, and infrared radiation.

7XX - HEALTH PHYSICS-(3) This is a introductory course in basic physics concepts. The student will achieve a clear understanding of radiation protection issues directly associated with the handling of radioactive material and X-ray equipment. The focus of this course will be nuclear weapons technology, nuclear power generation, industrial applications, nuclear medicine, radiation therapy, and radiographic equipment.

7XX - ENVIRONMENTAL MANAGEMENT-(3) This is an introductory course in basic environmental management concepts. The student will achieve a clear understanding of air pollution, water pollution, and waste management issues. Waste management will include municipal waste, regulated waste, hazardous waste, and radioactive waste. Emphasis will be placed on waste stream characterization, reprocessing waste, and waste minimization strategies.

\section{c. Interdisciplinary}

ENVI 6XX CASE STUDIES IN ENVIRONMENTAL SCIENCE-(4) The course addresses basic scientific principles as they relate to environmental problems. The interdependence of the science disciplines will be stressed. Principles of 
biology, chemistry, geology, physics, and data analysis will be explored using specific case study scenarios.

ENVI 7XX CAPSTONE SEMINAR-(2) Under supervision of faculty from all tracks, students or student groups in this course analyze case studies from the various environmental aspects discussed in the core curriculum and in the course Environmental Sciences.

\section{ENVI 7XX RESEARCH}

\section{ENVI 7XX THESIS}

\section{Existing Courses Relevant to the Program}

a. UCSC

\section{Biology}

BIOL 510 - FIELD METHODS IN MARINE ECOLOGY-(2) The use of ecological theory and methods to obtain and interpret experimental data gathered in the local marine environment. Emphasis will be placed on an intensive class project. Lecture and laboratory total 4 hours per week. Prerequisites: one year of chemistry, mathematics through algebra and trigonometry or introductory calculus, BIOL 341 (Ecology).

BIOL 600 - PHYSIOLOGY AND CELL BIOLOGY OF MARINE ORGANISMS-(4)

A study of the regulatory mechanisms found in marine organisms especially as they relate to interactions between the organism and the environment. Mechanisms will be discussed at the organismal, organ-system, tissue, and cellular levels. Lectures, three hours per week; laboratory, three hours per week.

BIOL 601 - POPULATION BIOLOGY AND ECOLOGY OF MARINE ORGANISMS- (4) The study of living organisms in the marine environment population and community ecology, reproduction and life histories, productivity, evolution and biogeography. A broad overview of these elements is followed by detailed consideration of major coastal and oceanic ecosystems around the world. Lectures, three hours per week; laboratory, three hours per week.

BIOL 610 - PHYSICAL OCEANOGRAPHY-(4) A study of the physics and chemistry of ocean and estuarine water, circulation, waves and tides. Lecture and laboratory work will emphasize the interrelationships of physical, chemical, geological, and biological processes in the sea. Lectures, three hours per week; laboratory, three hours per week. 
BIOL 611 - BIOMETRY-(4) A broad treatment of statistics concentrating on specific statistical techniques used in marine biological research. Topics covered include sampling procedures and analysis of distributions (binomial, poisson, and normal) hypothesis testing and estimation with emphasis on analysis of variance and experimental design (latin-square, nested, randomized block, factorial), analysis of frequencies, regression, and correlation. Several nonparametric and multivariate methods which are pertinent to research in the marine biological science are also discussed. Although course emphasis is oriented toward application of statistical techniques and not toward theory, a knowledge of mathematics through calculus is expected. Lectures, three hours per week; laboratory, one hour per week.

BIOL 640 - APPLIED AND ENVIRONMENTAL MICROBIOLOGY-(4) A lecture and laboratory study of the special applications of microbiology to domestic water and wastewater and solid wastes, food and dairy products, agriculture, and industrial processes. Includes microbial distribution and its role in various marine and freshwater, terrestrial, animal, atmospheric, and product environments. Lectures, three hours per week; laboratory, three hours per week. Prerequisites: BIOL 310 (General Microbiology with lab) and one year of Chemistry.

BIOL 642 -AQUATIC TOXICOLOGY-(4) An introduction to assessing the effects of toxic substances on aquatic organisms and ecosystems. Topics include general principles of toxicology, fate and transport models, quantitative structure-activity relationships, single-species and community-level toxicity measures, regulatory issues, and career opportunities. Examples will be drawn from marine, freshwater and brackish-water systems. Lectures, three hours per week; laboratory three hours per week.

BIOL 643 - FISHERIES SCIENCE-(3) A general introduction to methods of harvesting aquatic resources and collection and evaluation of biological data to effectively manage these resources. Topics include age and growth analysis; mortality, recruitment, and yield; production and early life history; stock assessment techniques; and detailed study of a certain important fisheries. Lectures, three hours per week.

BIOL 644 - AQUACULTURE-(3) Principles and techniques of aquaculture, with emphasis on warm-water species which spend all or part of their lives in salt water. Status and potential of aquaculture, including detailed discussions of established and candidate species. Design and management of aquaculture systems. Importance of water quality, feeding and nutrition, diseases and predators, geiletics and breeding, and economic considerations in aquaculture. Lectures, three hours per week. 


\section{Chemistry}

CHEM 522 - ENVIRONMENTAL CHEMISTRY-(3) An introduction to the chemistry of natural systems with an emphasis on marine and coastal problems. The cycling of chemical species, the effect of man-made inputs and environmental analytical methodology will be stressed. Lectures, three hours per week. Prerequisite: CHEM 221, Quantitative Analysis

CHEM 522L - ENVIRONMENTAL CHEMISTRY LABORATORY-(1) An introduction to sampling and measurement techniques used to characterize the environment. Electrochemical, spectroscopic, and chromatographic techniques will be used with both laboratory and field investigations. Laboratory, three hours per week. Corequisite: CHEM 522

CHEM 524 - ENVIRONMENTAL ANALYTICAL CHEMISTRY-(3) A course stressing the applications of analytical chemistry to environmental problems. Spectroscopic, chromatographic, and classical analytical methodologies will be discussed. Certification requirements for data, quality assurance of laboratory measurements, laboratory information management systems, (LIMS), and report writing will be discussed in the framework of the analytical laboratory. Lecture, 3 hours per week. Prerequisites: CHEM 521 OR CHEM 522 or permission of the instructor.

CHEM 526 - INTRODUCTION TO NUCLEAR AND RADIOCHEMISTRY-(1) An introduction to the fundamental theories and applications of nuclear and radiochemistry. This short course surveys the structure of the nucleus, radioactive decay modes, the detection and measurement of nuclear radiation, and application of radiochemical methods, to medical, environmental, and scientific problems. This course is typically taught as part of the Special Topics in Chemistry sequence. Lectures, three hours per week for 5 weeks. Prerequisite: CHEM 221 OR CHEM 231 or permission of the instructor.

CHEM 528 - NUCLEAR AND RADIOCHEMISTRY-(3) An introduction to nuclear and radiochemistry stressing the fundamentals of nuclear structure, systematics of nuclear decay, the detection and measurement of radiation, radiation protection, and the role of nuclear chemistry in medical, environmental, and scientific applications. The nuclear fuel cycle and nuclear waste problems will be discussed. Lectures, three hours per week. Prerequisite: CHEM 221 or permission of the instructor.

\section{Public Administration}

PUBA 502 B POLITICS IN GOVERNMENTAL REGULATION-(3) This course is intended to introduce students to the economic, legal and political consequences 
of government regulation. Within this general framework, the following topics and objectives are addressed:

1) the major causes and justifications (economic, political) for regulation;

2) the solicited and unsolicited consequences of regulation on the prices, availability, and quality of goods and services; power;

3) The major statutory, executive, and judicial checks on regulatory

4) the regulatory process as it operates in several major federal and state agencies, including OSHA, public services commissions, the FTC, and the FDA:

5) the current frenzy concerning "deregulation", and its impact on the quality of life for the nation's citizens.

PUBA 502D COASTAL RESOURCE MANAGEMENT-(3) This unique crossdisciplinary course will address the complex issues that are confronting us today at the water's edge. A rapidly developing area, the coast of South Carolina, generates more than $40 \%$ of the state's economic activity. Both its population and economic importance are expected to increase dramatically as we move into the 21st century. Demands for economic development and environmental protection involve issues that are scientifically, economically, and politically complex and often conflicting. We must expand our scientific understanding of coastal ecosystems and the interrelationship with man's activities and associated impacts.

PUBA 502 P ENVIRONMENTAL POLITICS-(3) This course encompasses environmental politics and policy, first from a macro perspective, then through a focus on the politics of waste: nuclear, hazardous, and solid. Special attention is given to waste politics and policy in South Carolina. Theoretical issues and approaches to environmental politics are considered as well as "what can we do?"

PUBA 510 COMPUTERS IN GOVERNMENT This course orients students to the utilization of computers in various governmental activities, primarily in development and utilization of management information systems. Includes familiarization with program applications including spreadsheets, statistical packages, desktop systems, and work processing.

PUBA 600 PERSPECTIVES ON PUBLIC ADMINISTRATION-(3) The study and practice of public administration in the United States in the 20th century. This course examines the historical development of the field of public administration and current approaches to the study and practice of public administration.

PUBA 602 PUBLIC POLICY PROCESS-(3) This course seeks to develop a firm understanding of the public policy making in the United States. Students study policy making through various perspectives on implementation. The roles of major institutions including the Executive, Congressional, and Judicial branches 
of government, the bureaucracy and interest groups in this process are addressed. Integrated within this study of the process are various perspectives and interpretations of policy making, including, incrementalism, rationalism, pluralism, and elitism. Selected areas of public policy, including transportation, poverty, energy, and the environment are used to illustrate both the process and different perspectives.

PUBA 605 FINANCIAL ADMINISTRATION -(3) This course is designed to give an overview of financial administration in government. The goal is to sensitize you to the major issues surrounding various issues of financial administration and to acquaint students with the basic terms and concepts associated with the areas. Financial administration is broadly interpreted to address all the various dimensions of raising, spending, and accounting for money in government.

PUBA 608 ADMINISTRATIVE ETHICS AND ACCOUNTABILITY A critical examination of the legal, political, professional, and organizational accountability demands made on administrators and their relationship to ethical decision making and ethical integrity.

PUBA 611 URBAN PUBLIC POLICY-(3) This course examines the context and nature of the urban policy making system in the US. Focus is on theories of urban policy, formulation of policy, and implementation of policy, especially in the service system. The role of citizen participation, and influences of state and federal governments are considered. Specific urban policy areas are overviewed.

PUBA 622 INTERGOVERNMENTAL RELATIONS-(3) This course is designed to give an overview of intergovernmental relations. As such, it seeks to acquaint the student with significant features of federalism from both a legal and practical framework. The course begins with an emphasis of the historical grounding of federalism in the US Constitution and evolution of federalism as the country has moved from an rural base to an urban, industrialized, internationalized economy. Attention is paid to significant areas of governmental relations, including fiscal and other policy areas s'xch as environmental issues, energy policy, education, and the like.

PUBA 631 ADMINISTRATIVE LAW-(3) A study of the legislative, adjudicatory, and general policy-making powers of administrative agencies and regulatory commissions, and the scope of judicial review of administrative action. The course is directed primarily toward an analysis of the procedural requirements and political aspects of administrative policy-making. Bureaucratic discretion and the interaction of administrative law and politics are central to the course content.

PUBA 663 POLICY EVALUATION-(3) This course provides an understanding of the nature and role of evaluation research, its relationship to the policy 
process, and its consequences. The historical development of techniques of evaluation is addressed, with specific attention to post-World War II techniques and theories such as information theory and general systems theory. Policy evaluation is broadly broken into qualitative and quantitative techniques. Each of these is discussed with respect to its appropriateness and applicability.

PUBA 706 ECONOMICAL THEORY FOR POLICY ANALYSIS-(3) This course develops and applies microeconomic models and theory to the analysis of contemporary public sector issues. Attention is given to the conceptual and practical problems associated with resource allocation decisions when their is conflict among efficiency, equity, and limited information in policy making. The foundations of welfare economy and techniques and applications of cost-benefit analysis as they relate to specific policy areas and programs are examined as well.

PUBA 712 - ORGANIZATIONAL BEHAVIOR-(3) A survey of theories of organization behavior from the classical to systems perspectives. The objective is to provide a conceptual framework for the understanding and study of organizational behavior and human behavior in organizations. Topics to be discussed will include formal and informal structure, motivation, organizational environments, decision-making, leadership and organizational change and development.

PUBA 722 - INFORMATION SYSTEMS AND PUBLIC ADMINISTRATION-(3) The development of uses of information systems in local, state, and federal administrative agencies with emphasis on the management of information systems in the public agency environment; the problems of interagency and intergovernmental relations; the politics of technological innovation; privacy, confidentiality, and security and information policy; and the role of information technology in democratic government.

\section{b. MUSC}

\section{Biometry \& Epidemiology}

10-700 INTRODUCTION TO BIOSTATISTICS-(4) This is an introductory course in statistical methodology. Included in this course are data collection, display and synthesis, the concept of a population and a sample, in particular, a random sample, confidence intervals, tests of significance, analysis of enumeration data, correlation and regression, analysis of variance and nonparametric methods.

10-702 INTRODUCTION TO EXPERIMENTAL DESIGN-(3) The course emphasizes designs that are used widely in statistics. The Latin Square design, factorial design, two-way design with interaction are discussed. In addition, multiple regression models are studied as an introduction to basic non- 
parametric procedures in analysis of variance. Other topics covered as time allows and student interest prevails include life tables, nested and confounded designs, and analysis of covariance. (Prerequisite: 10-700).

10-704 NONPARAMETRIC METHODS IN BIOLOGY AND MEDICINE-(3) This course discusses: levels of measurements, order statistics, statistical methods for independent and correlated samples, distribution free association measures and testing. Objectives are: to alert students to situations where parametric techniques do not apply; to introduce students to nonparametric methods for testing equality of variances; to enable students to test data goodness of fit to a probability distribution; and to teach students to measure degree of association involving samples from non-normal populations. (Prerequisite: 10-700 and 10706).

10-706 THEORETICAL FOUNDATIONS OF STATISTICS I-(3) This course covers in detail probability, probability spaces, random variables, probability distributions (both discrete and continuous), moments, and moment generating functions, including expectations and variances. Special distributions, include the normal, $t$, chi-square, $F$, binomial, Poisson, gamma, and beta. In addition, topics in stochastic convergence and central limit theorem are covered. (Prerequisites: Differential and integral calculus).

10-710 REGRESSION METHODS IN BIOLOGY AND MEDICINE-(3) Covers techniques in regression analysis including the least squares equation, methods for adding and eliminating variables in a regression model as well as plotting techniques. The SAS software system is used, and emphasis is placed on the application of regression methods and the interpretation of results. (Prerequisite: 10-700).

10-711 ANALYSIS OF CATEGORICAL DATA-(3) This application oriented course is intended for Ph.D. and advanced M.S. students. It offer a short review of standard chi-square methods is followed by several special purpose techniques for two-dimensional tables. Other areas covered include the logic transformation, maximum likelihood and weighted least squares methodologies, analysis of three-dimensional and higher tables, and treatment of zero cells. (Prerequisite: 10-707 or 10-710).

10-712 SAMPLING METHODS IN BIOLOGY AND MEDICINE I-(3) Estimation of parameters of a finite population from samples drawn with and without replacement. Simple random samples, cluster and stratified samples, confidence intervals for parameters, optimal allocation and required sample size are also covered. (Prerequisites: 10-702 and 10-706).

10-718 STOCHASTIC BIOLOGICAL PROCESSES I-(3) Starts with an introduction overview of the role of Stochastic Processes in Biomedical Systems. This is followed by a review of relevant probability and statistical theory, 
including probability generating functions. The course provides an introduction to the following: The Poisson Process, Renewal Theory, Markov Decision Processes; Semi-Markov Decision Processes, Inventory Theory; and Continuoustime Stochastic Optimization Models. (Prerequisite: 10-706).

10-722 ANALYSIS OF SURVIVAL DATA I-(3) An introductory course in the theory and applications of methods in survival analysis, both parametric and nonparametric, to actual survival data. Topics covered include: (1) the basic parametric, survival distributions including the exponential, Weibull and lognormal, (2) censoring of observations, (3) the Product Limit estimator, (4) parameter estimation, (5) nonparametric methods, (6) regression techniques including Cox's model, (7) bivariate models and (8) other topics as time allows including asymptotic properties of estimators. (Prerequisite 10-706).

10-724 CLINICAL TRIALS THEORY AND METHODS-(3) This course is intended to be a comprehensive course on the theory and methods of clinical trial. Aspects that are covered include the design of the clinical trial and the analysis of data that are obtained from a clinical trial, potential and actual problems that occur in clinical trials such as misclassification of patients, failure to follow the protocol and patient noncompliance, sample size required for a fixed sample clinical trial and various adaptive methods for a variable sample clinical trial. The course is designed primarily for students in the Department of Biostatistics, Epidemiology, and Systems Sciences. However, both clinicians and basic scientists can benefit from this course provided they have the required background in mathematics and statistics. (Prerequisites: 10-706 and 10-710).

10-726 MULTIVARIATE METHODS IN BIOLOGY AND MEDICINE I-(3) This will consist of multivariate techniques in biology and medicine including multivariate tests of mean vectors and covariance matrices, multivariate analysis of variance, canonical correlation, factor analysis, principal components, discriminant analysis and multivariate regression. (Prerequisites: 10-702 and 10706).

10-730 QUANTITATIVE METHODS IN EPIDEMIOLOGY- (3) This course provides a survey of basic biostatistical methods used in observational and experimental epidemiologic investigations. Topics include rates and rate standardization, relative risk, odds ratio, attributable risk, adjustment of data, life-table analysis, Kaplan-Meier product-limit method, nonparametric methods for comparing exposure groups including log-rank test and Mantel-Haenszel chisquare test, survey sampling. Emphasis is on applications of analytical methods to the analysis of real-life data including data from the Charleston Heart Study and the Framingham Study. Relevant statistical software, including SAS, will be used. (Prerequisite: 10-700).

10-732 INTRODUCTION TO EPIDEMIOLOGICAL LITERATURE-(3) The application of epidemiologic and statistical principles to the interpretation of 
literature in the field. Through oral presentations and discussions students learn to: summarize the research questions, the study design and the results of scientific papers; evaluate and criticize the methodology used and conclusions drawn; and to articulate new contributions to knowledge made by specific research projects.

10-736 EPIDEMIOLOGICAL FOUNDATIONS-(3) Introduction to basic epidemiologic principles including measurements of disease occurrence, study designs (cohort, case-control, randomized clinical trials) and calculation of risk. Lecture material is supplemented with exercises and discussion of examples from the epidemiologic literature.

10-738 ADVANCED EPIDEMIOLOGY: DESIGN AND CONDUCT OF EPIDEMIOLOGIC STUDIES-(3) Provides students with the knowledge and skills necessary to design, carry out and interpret epidemiologic studies of acute and chronic diseases. Topics include sources of data, methods of sampling, survey methods, questionnaire design, quality control, management and examination of data, planning analyses and presentation of results. (Prerequisite: 10-736).

10-740 INTRODUCTION TO STATISTICAL COMPUTING AND DATA MANAGEMENT-(3) Introduction to use of computers to store and process both small and very large data sets. Experience with data file management and manipulation using computer languages and software such as COPY, dbase, minitab, BMDP, SAS and graphics packages is obtained. Methods of storing, accessing and managing data are emphasized.

10-741 PRINCIPLES OF DIGITAL COMPUTING AND PROGRAMMING(3) This course provides an introduction to computer science and programming using Pascal programming language. Its aim is to give the student a general introduction to problem solving with a computer, emphasizing top-down design, modularity, and reusability. Planning, documentation, readability and careful testing, and principles of modern software engineering are stressed throughout. All programs are tested using Turbo Pascal on an IBM AT/PS. The fundamentals of microcomputer hardware and software are also covered.

10-742 COMPUTER SYSTEMS AND LANGUAGES I-(3) This course presents an introduction to computer architecture and assembly language programming. Switching circuit and digital logic are discussed, then the concepts are applied to the design and operation of digital computers. Programming experience in assembly language is emphasized with micro-processors, which includes instruction sets, addressing modes, $\mathrm{I} / \mathrm{O}$, and interruption.

10-750 INTRODUCTION TO BIOMEDICAL SYSTEMS ANALYSIS-(3)

This introductory course primarily addresses students in the Department of Biostatistics, Epidemiology, and Systems Science, but is also open to interested students from other programs. It introduces basic mathematical tools for the 
quantitative and numerical analysis of biomedical phenomena and systems. The course is divided into mathematical and computational parts which complement each other and are presented side by side. All concepts and methods of mathematical and computer-aided analysis are applied to examples from biology and medicine. (Prerequisites: Admission to Biometry and Epidemiology or permission of instructor).

10-752 BIOLOGICAL SYSTEMS ANALYSIS I - LINEAR SYSTEMS-(3) The course emphasizes the application of systems concepts and methods to the study of biological systems. The course is split approximately evenly between tutorial material and reviewing research reports from the biomedical literature. Advanced topics include coding and codes, information theory, difference machines, and white noise analysis. (Prerequisite: 10-750).

10-754 BIOLOGICAL SYSTEMS ANALYSIS II - NONLINEAR SYSTEMS(3) This course introduces concepts and methods of analysis for non-linear systems. Such concepts include different types of singularities, equilibria, bifurcations, stability, oscillations, catastrophes, and chaos. Emphasis will be placed on utilizing the mathematical models to understand the biomedical system as well as the mathematical derivations. (Prerequisite: $10-750$ or 752).

10-762 MODELING AND SIMULATION-(3) The course offers theoretical and applied aspects of modeling and simulation. In the theoretical part, mathematical and computational techniques are discussed and illustrated with work from the literature. Differences and similarities between discrete and continuous models and between deterministic and stochastic models are analyzed. Linear and nonlinear compartment models are emphasized since they are of particular interest in biomedical applications. In the applied part, the student obtains hands-on experience by developing and analyzing biomedical models from first principles. (Prerequisites: 10-750 or 10-752).

10-766 MEDICAL INFORMATION SYSTEMS-(3) This is an elucidation of the current state of the art of computer applications for the provision of medical care. The course will emphasize data base structure and information system development. An overview also will be presented on uses of the computer in other areas of application and research in medical care. (Prerequisite: 10-740).

10-768 ARTIFICIAL INTELLIGENCE IN MEDICINE-(3) An introduction to the research methods and application areas of medical artificial intelligence. Along with an introduction to the LISP programming language, major topics in artificial intelligence research will be covered and some existing medical AI systems will be discussed. Students are expected to complete programming assignments and projects which reflect the basic principles and techniques of artificial intelligence. (Prerequisite: 10-742). 
10-789 SPECIAL TOPICS-(1-3) Individual arrangements may be made by the advanced student to conduct supervised investigation into selected problem areas in Biostatistics, Epidemiology, and Systems Science. Such areas include elements of stochastic biological processes, bioassay techniques, sequential trials, biomathematics, and advanced computer topics. This course may be repeated with change of content up to a maximum of fifteen hours. (Prerequisite: Permission of instructor).

\section{Basic Science Departments}

11-602 G CORE BIOCHEMISTRY-(9) Offers a fundamental understanding of the biochemistry and chemistry of carbohydrates, lipids, proteins, and nucleic acids. Advanced topics on intermediary metabolism, molecular biology, control mechanisms, acid base balance, the endocrine system, and special features of organ systems are presented. Prerequisite: organic chemistry

51-734 DRUG-RECEPTOR INTERACTIONS - (3) Directed toward students of the biomedical sciences who wish to develop a molecular approach to the basis of drug action. Introduces the physical and organic chemistry of drugs, receptors and their interactions, and the effects of drug-receptor interactions at the subcellular and cellular levels. Throughout the course, the student attends lectures and solves assigned problems that are oriented toward the elucidation of molecular mechanisms by which drugs elicit their response in living organisms.

51-736 DRUG METABOLISM AND PHARMACOKINETICS-(4) Introduction to biochemical and cell biology aspects of pharmacology with emphasis on pharmacokinetics and drug metabolism. Topics include drug absorption, distribution, biotransformation, and excretion, together with an introduction to the role of reactive metabolites in drug toxicity and chemical carcinogenicity. Consideration is given to the role of isolated cell suspensions in the study of the metabolism and cytotoxicity of drugs and other xenobiotics. Prerequisites: 11-602 G, 51-734.

53-745 PHARMACOKINETICS I-(3) Detailed presentation of mathematical bases and assumptions underlying the compartmental systems, multiple dosing, apparent volumes of distribution, bioavailability, kinetics of pharmacological effects, non-linear pharmacokinetics, routes of administration, and drug distribution. Prerequisites: calculus, basic biopharmaceutics, basic pharmacokinetics.

\section{FACULTY}

A. Graduate Faculty Status 
In order to supervise student research, faculty at MUSC and UCSC must be members of the Graduate Faculty. To be appointed to the Graduate Faculty, an individual must

1. have an earned terminal degree;

2. have the rank of Assistant Professor or above;

3. show evidence of productive scholarship, including recent publications of original investigations in edited journals, extramural research support, and recognition of research competency by peers, such as membership on national research review committees;

4. demonstrate active or planned participation in graduate education through teaching, serving on graduate committees, and other activities relevant to graduate student training;

5. be actively involved in original scientific research.

Faculty members are appointed to the Graduate Faculty for a term of five years. At the end of this period, the faculty will be asked if they wish to continue their appointment indicating they have a continuing interest in graduate education and research. The purpose of this reappointment system is to maintain an active Graduate Faculty. Continued appointment is dependent on the faculty member having some role in graduate education and maintaining scholarly pursuits.

Members of the faculty of Clemson University (see below for names and Appendix for Curricula Vitarum) will be considered for adjunct appointments to the Graduate Faculty at MUSC or UCSC. The same criteria apply to these faculty as to MUSC and UCSC faculty.

\section{B. Current Faculty \\ (Curricula Vitarum are presented in the Appendix)}

\section{MUSC}

The faculty listed are those at MUSC and UCSC. Every effort will be made to invite participation of faculty from the other South Carolina universities whose expertise will complement the strengths at MUSC/UCSC. The ongoing dialog that is currently occuring will greatly assist the communication of this information.

The Department of Biometry and Epidemiology (BIOM/EPID) at MUSC has a strong faculty that is currently offering a Master's program and that will be able to offer the proposed program. The department has 16 full-time faculty and 2 joint faculty with doctorate degrees; almost all of them have published technical papers or books in the past three years. This research and publication record by far exceeds that of schools in the Southeast that offer Master's but not doctoral 
programs. For example, the American Mathematical Society has published figures that show that the average faculty in these departments is about 23, of which 12 have published in the past three years.

In addition, MUSC has strong faculty in the areas of toxicology, biochemistry, and microbiology. These faculty have active research programs which will complement the proposed program.

Karen G. Burnett - Ph.D., University of South Carolina. Associate Professor. Background: Marine Biomedicine, Immunology and Molecular Biology of Marine Organisms.

Rosalie K. Crouch - Ph.D., Yeshiva University. Professor and Dean. Primary research Area: Biochemistry of Rhodopsin.

James K. Dias - Ph.D., Medical University of South Carolina. Assistant Professor. Applications of Statistics to Environment, Marine Sciences and Biology, Health Services Research.

DiBona, Donald R. - Ph.D., Iowa State University. Professor. Research Areas: Cell Volume Regulation, Marine Biology.

John B. Dunbar - D.M.D., University of Alabama, and Dr. P.H., Tulane University. Professor. Interests: Epidemiology of Hypertension, Atherosclerosis, Coronary Heart Disease.

Alan J. Gross - Ph.D., University of North Carolina. Professor. Research Areas: Life Tables, Survival and Reliability Theory, Stochastic Processes, Outlier Theory, Sample Size Determination.

David G. Hoel - Ph.D., University of North Carolina. Professor and Chairman of Biometry \& Epidemiology. Background: Environmental Epidemiology, Risk Assessment.

Thomas C. Hulsey - Dr. Sc., Johns Hopkins School of Hygiene \& Public Health. Assistant Professor. Areas: Epidemiology of Maternal and Child Health, Family Planning.

Hurshell H. Hunt - Ph.D., Oklahoma State University. Associate Professor. Research Areas: Sampling, Probability Distribution Theory, Bayesian Statistics, Estimation, Outlier Theory.

James A. Johnson Jr. - Ph.D., Florida State University. Associate Professor and Chairman. Areas of Interest: Hospital Policies and Administration. 
David Jollow - Ph.D., Monash University. Professor. Research Areas: Toxicology, Biomarkers, Drug Metabolism.

Rebecca G. Knapp - Ph.D., Medical University of South Carolina. Associate Professor in Biostatistics, Epidemiology and Systems Sciences, Nursing, and Health Related Professions. Research Areas: Biostatistics, Evaluation Methodology.

Chan F. Lam - Ph.D., Clemson University. Professor. Research Areas: Signal Analysis, Image Processing, Pattern Recognition, Modeling and Simulation, Optimization, System Analysis, Biomedical Engineering, Expert Systems.

George Lindenmayer - M.D., Ph.D., Baylor College of Medicine. Professor. Primary Interest: Biochemistry of Sodium/Calcium Exchangers.

G. Patrick Meier - Ph.D., University of Wisconsin. Assistant Professor. Research Areas: Biochemistry, Drug Metabolism.

David McMillan - Ph.D., University of Arkansas for Medical Sciences. Assistant Professor. Research Areas: Hemotoxicity, Drug Metabolism.

JoEllyn McMillan - Ph.D., Texas A\&M University. Assistant Professor. Research Areas: Biochemistry, Drug Metabolism.

M. Clinton Miller, III - Ph.D., University of Oklahoma Medical Center. Professor. Research Areas: Experimental Design, Health Care Systems Evaluation, Epidemiological Models, Medical Decision Models, Operations Research, Quality Control.

Yuko Y. Palesch - Ph.D., George Washington University. Assistant Professor. Research Areas: Markov and Martingale Processes, Survival Analysis, Clinical Trials, Multivariate Analysis, Biostatistics, Epidemiology and Demography of Ageing.

John S. Ramsdell - Ph.D., University of California, San Francisco. Assistant Professor. Research Areas: Cell Biology, Growth Mechanisms, Marine Toxins.

Michael J. Reed - M.S., University of North Carolina. Assistant Professor. Areas of Interest: Chemical Engineering, Industrial Hygiene.

Philip F. Rust - Ph.D., University of California at Berkeley. Associate Professor. Research Areas: Markov Processes, Stochastic Processes, Nonparametrics, Statistical Distributions, Categorical Analysis, Genetics, and Epidemiology.

Michael Schmidt - Ph.D., Indiana University. Assistant Professor. Research Areas: Selenite Metabolism, Biodegradation. 
L. William Stillway - Ph.D., University of Idaho. Professor. Research Areas: Organic Chemistry, Biochemistry.

Susan E. Sutherland - Ph. D., Medical University of South Carolina. Assistant Professor. Areas of Interest: Biostatistical Consulting, Statistical Computing.

Janet Z. Temple - Ph. D., Colorado State University. Assistant Professor and Chairman of Department of Environmental Health. Areas of Interest: Environmental Compliance, Hazardous Waste.

Eberhard O. Voit - Ph.D., Universität zu Köln. Associate Professor. Research Areas: Biomathematics, Nonlinear Modelling, Simulation, S-Systems, Cell Cycles, Populations Dynamics.

Thomas Walle - Ph.D., Royal Institute of Pharmacy, Sweden. Professor. Research Interests: Metabolism, Pharmacokinetics.

Zhen Zhang - Ph.D., University of Pittsburgh. Assistant Professor. Research Areas: Image and Signal Processing and Interpretation, Artificial Intelligence.

\section{UCSC}

Faculty from two schools and six departments will participate in the program. The Institute of Public Affairs and Policy Studies shares faculty in the Department of Political Science (School of Humanities and Social Sciences) and will primarily staff the courses in the policy area. Five departments in the School of Sciences and Mathematics, including the Departments of Biology, Chemistry, Geology, Mathematics, and Physics, will provide support primarily in the basic sciences. The faculty in the Departments of Biology, Mathematics, and Political Sciences currently participate in the graduate programs through their departments.

Asleson, Gary - Ph.D., University of Iowa. Associate Professor of Chemistry. Analytical chemistry, NMR spectroscopy; environmentally oriented analytical chemistry problems.

Baldwin, Sara - Ph.D., W. Virginia University. Assistant Professor of Geology. Karst geomorphology and hydrogeology.

Beam, Charles F. - Ph.D., University of Maryland. Professor of Chemistry. Strong-base organic synthesis using multiple anions; polymer/monomer synthesis and characterization. 
Burnett, Louis E. - Ph.D., University of South Carolina. Professor of Biology. environmental physiology of organisms, especially respiratory, acid-base and ion transport.

Carew, James L. - Ph.D., University of Texas, Austin. Professor. Research Areas: Carbonate petrology, paleoecology.

Colgan, Mitchell W. - Ph.D., University of California, Santa Cruz. Assistant Professor of Geology. Reef ecologist with specialties in remote sensing; environmental geology and climatology.

Deavor, James - Ph.D., University of South Carolina. Assistant Professor of Chemistry. Analytical chemistry with specialty in determining trace elements/material in the environment.

Dillon, Robert, Jr. - Ph.D., University of Pennsylvania. Associate Professor of Biology. Genetics, especially of mollusks; electrophoretic analysis of gene frequencies at enzyme loci; the roles of natural selection and gene flow in divergence and speciation of isolated freshwater snail populations; the importance of particular isozymes for growth and survivorship in hatchery populations of hard slams.

Dukes, Robert - Ph.D., University of Arizona. Professor. Astrophysics, elementary particles, atmospheric physics.

Dustan, Phillip - Ph.D., Sate University of New York at Stony Brook. Associate Professor of Biology. Ecology and estuarine fronts and the distribution of primary productivity in river, estuarine, and coastal waters. Remote sensing and photoecology of coral reefs and phytoplankton communities. Ecology and vitality of reef-building corals in the Florida Keys.

Felts, Arthur A. - Ph.D., Pennsylvania State University. Associate Professor of Political Science, Public administration and public policy, intergovernmental relations.

Fronabarger, Allen K. - Ph.D., University of Tennessee, Knoxville. Assistant Professor. Interests: Igneous petrology, geochemistry.

Harrison, Gary - Ph.D., Michigan State University. Professor of Mathematics. Mathematical biology, moving finite-element methods in predator-prey problems, models of geriatric flow problems.

Johnson, Robert K. - Ph.D., Scripps Institute of Oceanography, University of California, San Diego. Professor of Biology. Systematics, ecology, and zoogeography of mesopelagic fishes; nearshore fishes of the Gulf of Honduras, Central America. 
Jones, Martin - Ph.D., Georgia Institute of Technology. Assistant Professor of Mathematics. Probability and statistics, optimal stopping problems.

Katuna, Michael P. - Ph.D., University of North Carolina. Professor of Geology. Marine and coastal geology, stratigraphy and sedimentation; specialties are coastal processes and subsurface stratigraphy.

Kinard, Frank W. - Ph.D., University of South Carolina. Professor of Chemistry. Analytical and nuclear chemistry; liaison between the University of Charleston and the nuclear power plant at Savannah River.

Logan, Roger - Ph.D., Kansas State University. Assistant Professor of Mathematics. Mathematical biology, dynamics of predator-prey models.

Luo, Zhexi - Ph.D., University of California at Berkeley. Assistant Professor of Biology. Anatomy and functional morphology of vertebrates; evolutionary history and phylogenetic relationships of mammals; phylogenetic transformations and functions of the mammalian ear structures; study of vertebrate structures by using computerized reconstructions and morphometrics.

McCarthy, Robert - Ph.D., Dartmouth College. Assistant Professor of Biology. Cell-interactions and cell differentiation during development, involvement of cell surface and/or extracellular matrix molecules which may regulate the adhesions, migration and/or differentiation of cells.

Metz, Clyde - Ph.D., Indiana University. Professor of Chemistry. Physical chemistry; physical measurements of fused salt systems.

Mills, Laney - Ph.D., Louisiana State University. Associate Professor. Optics, Quantum Theory, Atmospheric Physics.

Morrison, Susan J. - Ph.D., Florida Sate University. Assistant Professor of Biology. Estuarine and marine microbiology, sanitary microbiology distribution and survival of pathogenic bacteria in estuarine environments.

Nations, Harold - Ph.D., Pennsylvania State. Assistant Professor. Astrophysics and astronomy.

Nivison, Helen T.- Ph.D., University of California, Davis. Assistant Professor of Biology. Interests: Plant physiology.

Norton, Robert - Ph.D., Oklahoma State University. Professor of Mathematics. Quality control, nonparametric statistics, applications of probability distributions. 
Nusbaum, Robert L. - Ph.D., University of Missouri at Rolla. Associate Professor of Geology. Mineralogist, volcanologist; remote sensing and environmental geochemistry.

Packer, Lindsay - Ph.D., University of Texas. Assistant Professor of Mathematics. Partial differential equations, economic modeling and forecasting.

Ritchie, Alexander W. - Ph.D., University of Texas, Austin. Professor. Background: Structural geology and tectonics.

Runey, Martha W. - Ph.D., University of South Carolina. Associate Professor of Biology. Gametogenesis and fertilization in nematodes of amphibians; distribution and intensity of parasitic infections in estuarine organisms.

Sautter, Leslie R. - Ph.D., University of South Carolina. Adjunct. Interests: Marine geology, stable isotopes of planctonic Foraminifera.

Scholtens, Brian - Ph.D., University of Michigan. Assistant Professor of Biology. Plant-insect interactions especially butterfly oviposition behavior; systematics of butterflies and moths.

Shanks, Alan - Ph.D., University of California at San Diego. Assistant Professor of Biology. Effect of an organism's behavior, coupled with the physics of the flow regime of the aquatic environment, on the organism's distribution, dispersal, and migration.

Smith, Denice - Ph.D., Dartmouth College. Assistant Professor of Biology. Cell motility in developing systems; pattern formation and its importance to the evolutionary process.

Starr, Christopher W. - Ph.D., Medical University of South Carolina. Assistant Professor. Interests: Signal analysis, biomedical computing.

Studer, Shannon - Ph.D., University of South Carolina. Assistant Professor of Chemistry. Physical chemistry, spectroscopy, wet methods synthesis.

Watts, Fred - Ph.D., Virginia Polytechnic Institute and State University. Professor of Physics. Neutron transport theory, teaching experience in nuclear physics.

Whitney, Carl L. - Ph.D., University of British Columbia. Assistant Professor of Biology. Animal behavior, song and territorial behavior in birds.

Wragg, Jeff - Ph.D., University of Missouri at Columbia. Assistant Professor of Physics. Background and teaching experience in nuclear physics. 


\section{Qualification of New Faculty}

At MUSC, all newly hired faculty will normally hold Ph.D. degrees. Senior faculty will have a strong track record of regular publishing in refereed journals, junior faculty will have to demonstrate strong potential for scholarly excellence. All newly hired faculty will be expected to obtain extramural funds in excess of $50 \%$ of their salary.

Before faculty are allowed to serve as student mentors, they have to be admitted to the Graduate Faculty. This requires them to excel in teaching, research, and grantsmanship. The appointment to the Graduate Faculty is for the duration of five years and is renewed if the faculty member still qualifies (see Section V.A. for details on Graduate Faculty status).

Specific research areas to be represented by new faculty include Health Policy, Environmental Epidemiology, Environmental Modeling, Pharmacokinetics, Exposure Assessment, Risk Assessment, Environmental Microbiology, and Environmental Toxicology. It is noted that several faculty with expertise in some of these areas will be appointed independently of this proposal. Nonetheless, these faculty will be required to participate in teaching and student supervision.

Similar qualifications hold for new faculty at UCSC with the exception that faculty are not expected to obtain extramural funds in excess of $50 \%$ of their salary. Faculty will be sought in a variety of disciplinary areas, including Environmental Health Policy, Environmental Geochemistry, Environmental Chemistry, and Microbiology.

\section{Proposed Changes in Assignment}

\section{MUSC}

The track in Risk Assessment is built on an exquisite infrastructure within Biometry and Epidemiology. While several new courses will be added, a considerable body of elective courses is in existence and will be taught by the current course instructors. The Departments of Microbiology and Immunology and of Pharmacology will add courses which will be staffed in part by existing faculty members. The following reassignments will be necessary: 
The core courses will be staffed approximately as follows:

Drs. Hoel, Knapp and Voit will be reassigned to the courses Risk Assessment, Case Studies in Environmental Science, and Capstone Seminar.

Drs. Miller and Zhang will be reassigned to the course Operations Research and Decision Making.

Dr. Dunbar will be reassigned to the course Environmental Epidemiology.

Drs. Schmidt, Jollow, Meier, and McMillan will be reassigned to the courses Environmental Biology and Toxicology, Environmental Toxicology, Case Studies in Environmental Science, and Capstone Seminar.

Dr. K. Burnett and Mr. Reed will be reassigned to the course Case Studies in Environmental Science.

UCSC

Drs. Morrison and Dustan will be reassigned to the course Environmental Biology and Toxicology and Capstone Seminar.

Drs. Colgan and Dustan will be reassigned to the course Earth Systems Science.

Drs. Dukes and Wragg will be reassigned to the course Energy Production \& Resource Management.

Dr. Kinard will be reassigned to the courses Environmental Chemistry, Case Studies in Environmental Science, and Capstone Seminar.

Drs. L. Burnett, Felts and Katuna will be reassigned to the course Case Studies in Environmental Science.

Other existing elective courses will be taught by the current course instructors. The new elective courses will be taught by existing or new faculty. In cases where existing faculty are reassigned to these courses, new faculty will be hired for FTE replacement, according to Section V.E.

\section{E. Table of Current and New Faculty}

There are 4 different groups of faculty members: Current faculty without change in assignment; current faculty with (partial or full) reassignment to the program; new faculty assigned to the program; and new faculty assigned to replace current faculty teaching in the program. The following Table 6 enumerates the distribution of FTE's in these categories. 
Table 6: DISTRIBUTION OF FTE'S

Among Faculty Groups

Department

Current Faculty FTE's

New Faculty FTE Assignments

Not Reassigned Reassigned Program + Replacement $=$ Total

\begin{tabular}{|c|c|c|c|c|c|}
\hline MUSC & & & & & \\
\hline Biochemistry & 16 & 0 & 0 & 0 & $0^{*}$ \\
\hline Biometry \& Epid. & 15.25 & 0.75 & 0.75 & 0.75 & $1.5^{* *}$ \\
\hline Micro./Imm. & 13.5 & 0.5 & 0 & 0.5 & 0.5 \\
\hline Pharmacology & 21 & 1 & 0 & 1 & $1^{* *}$ \\
\hline UCSC & & & & & \\
\hline Biology & 20.5 & 0.5 & 0.5 & 0.5 & 1 \\
\hline Chemistry & 11 & 0 & 0 & 0 & $0^{*}$ \\
\hline Geology & 6.5 & 0.5 & 0.5 & 0.5 & 1 \\
\hline Mathematics & 26 & 0 & 0 & 0 & $0^{*}$ \\
\hline Physics & 8.5 & 0.5 & 0 & 0.5 & 0.5 \\
\hline Policy & 10.5 & 0.5 & 1.5 & 0.5 & 2 \\
\hline Total & 148.75 & 4.25 & 3.25 & 4.25 & 7.5 \\
\hline
\end{tabular}

\section{F. Faculty Development}

Faculty development in this program, as in all academic MUSC and UCSC departments, will ordinarily be achieved by the following activities:

a. Extramurally funded research grants and programs funded by federal and state agencies, industry, foundations, and other organizations which provide such funding.

b. Publication of their research in refereed scientific journals.

c. Presentation of their research results at scientific meetings and symposia. 
We shall study the feasibility of a newsletter on environmental issues, once the proposed program is under way.

Travel moneys proposed in the budget will be used to communicate outside MUSC and UCSC. The Program Steering Committee will decide on travel requests, according to set directions, and identify appropriate workshops, conferences, and other vehicles for professional growth

\section{G. Administration of Program}

A memorandum of understanding between MUSC and UCSC has internally clarified the responsibilities of and resources for each of the two institutions, as they relate to this proposal and to currently available DOE funds. According to this agreement, faculty positions will be made available at each institution, and both institutions will be represented in the administration and governance of this proposal. The fact that the DOE grant was awarded to MUSC should not be construed as an indication that MUSC would be the dominating force behind this proposal. It is noted that the DOE grant encompasses several tasks among which the development of educational programs is just one. Of the budget for educational purposes, a significant portion has been subcontracted to UCSC. As negotiated and documented in the memorandum of understanding between MUSC and UCSC, the proposed program will be a true joint venture with two equal partners.

The institutions will share responsibility for admission of students, management of budget and finances, and the granting of degrees. The degree diploma for graduates will carry the names of both institutions.

Initial funding for the program has been provided by the Department of Energy in the form of a grant. This grant covers salaries for faculty and staff, as well as start-up costs and overhead.

Initial graduate faculty for the program will be selected from the graduate faculties of the Medical University of South Carolina and the University of Charleston. While there exists a strong educational base, several new faculty will have to be hired to implement a successful program (see below).

The primary academic units administering the program are the Department of Biostatistics, Epidemiology, and Systems Science (Biometry \& Epidemiology) of the Medical University and the Institute for Public Affairs and Policy Studies and the School of Sciences and Mathematics of the University of Charleston. In addition, the MUSC Department of Pharmacology, the Department of Microbiology and Immunology, and the Department of Environmental Health Sciences will be involved in the program. 
d. Serving on editorial boards for scientific journals and other appropriate review boards for granting agencies.

e. Participation in various service activities for scientific and professional organizations.

f. Service oriented activities within the University involving both on-campus and off-campus activities.

In addition, several instituted and new procedures will stimulate the faculty members' professional growth.

Teaching

MUSC sponsors the Apple Tree Society for outstanding teachers. This society organizes annual workshops aimed at improving teaching skills.

MUSC awards the Golden Apple Award to outstanding teachers.

UCSC has regular teaching and faculty development workshops in place.

\section{Research}

MUSC and UCSC both provide institutional grants for establishing research in new areas. These grants do not allow for salaries but provide funds for equipment and start up costs. They have been very effective in the past as judged by successful subsequent submissions of extramural grant proposals.

\section{Science Communication}

MUSC has established a seminar and lecture series on environmental topics. This series is open to students and faculty at both institutions.

MUSC organizes an annual Student Research Day, where undergraduate and graduate students share their research results in the form of posters and oral presentations. The proposed program in Environmental Studies will participate in this activity.

We propose to foster communication between students and faculty of the two institutions with regular workshops in environmental studies. These workshops will include formal presentations as well as brainstorming sessions. 
A Program Director will be responsible for the administration of the program. The Director will hold appointments jointly at both universities and report to the Dean of Graduate Studies at MUSC and the Dean of Graduate Studies at the University of Charleston. The Deans will appoint a Coordinator in each of the major concentrations of Environmental Studies (Environmental Risk Assessment, Environmental Policy, and Environmental Science) to implement and administer the program. The Deans will appoint one additional individual in each of the major concentrations who, along with the Program Director and the disciplinary Coordinators, will serve as a Steering Committee for the program. The Steering Committee will be composed of an equal number of individuals from MUSC and the University of Charleston.

The Director will represent the Environmental Studies Programs on MUSC's Graduate Council. The Director and two individuals from the University of Charleston will represent the program on the University of Charleston's Graduate Council, in accord with standard practice at that institution.

The Steering Committee will admit graduate students into the program. According to the current policy at MUSC, all student admissions must be approved by the MUSC Graduate Council. Student admissions must also be approved by the UCSC Graduate Dean.

The Program Director will assist students in choosing a major advisor. The major advisor must be a member of the graduate faculty of MUSC or UCSC. This advisor will assist the student in the selection of courses, determination of the research subject, its scope, and its limitations, the direction of the thesis research, and the preparation of the thesis.

For students choosing a thesis or internship option, the student in consultation with the major advisor will establish a graduate committee consisting of the major advisor and a minimum of three other members. One member of the committee may be someone other than a member of the graduate faculty. The appointments will be approved and made by the Program Director.

The Steering Committee will approve curriculum changes in the program. Curriculum changes must also pass through the standard approval processes at each university.

The Steering Committee will also act on all petitions from students regarding any aspect of curriculum and program administrations. 


\section{PHYSICAL PLANT AND EQUIPMENT}

\section{A. Space}

Over the past decade, the Medical University has put enormous emphasis on physical plant development. This development has included several substantial expansions of clinical and basic science research space, the construction of the Hollings Oncology Center, and plans for the construction of a research building.

Especially relevant to this proposal is the appropriation of $\$ 1$ Million for the renovation of the 4th floor of the Student Life Center, which will be used for small and mid-size class and conference rooms. The rooms will be accessible to disabled students and faculty via elevators. These educational facilities will be ideally suited for courses of the proposed program.

Some new office space has been granted to Biometry and Epidemiology faculty on the 4th floor of the Harborview Office Tower. This space consists of six offices, a reception area, and a storage area for files and supplies. Additional expansions of Biometry and Epidemiology are under negotiation.

The University of Charleston continues to upgrade the space dedicated to the sciences. A teaching laboratory for Cell Biology and Molecular Biology will soon be renovated. Faculty/student research laboratories are slated for renovation. The University is also in the process of adding significant new space for faculty offices and teaching laboratories in the sciences. Space is currently being renovated outside the Science Center for teaching laboratories, and there are plans to acquire additional space to house more teaching and faculty/student research laboratories.

\section{B. Equipment}

A major portion of the MUSC commitment to this program rests with Biometry and Epidemiology. Teaching and research in this department are largely of a theoretical nature, requiring computer equipment, but no wet lab equipment. A substantial investment in this type of equipment has been negotiated between the administration, the new chairman of Biometry and Epidemiology, Dr. Hoel, and the Director of Libraries, Dr. Basler. Furthermore, Dr. Hoel has on loan from the National Institute of Environmental Health Sciences significant computing equipment that is ideally suited for the teaching and research needs in Biometry and Epidemiology

An analytical laboratory for geochemical analyses requires a number of items of specific equipment, including an inductively coupled plasma emission spectrometer and an ICP mass spectrometer. These instruments will be used for 
rapid elemental analysis of water, soil, and rock samples. In addition, highprecision isotopic and trace element analysis can be carried out.

Some of the equipment needs will be met through DOE funds. However, we plan to submit grant proposals for instrumentation to agencies such as EPA, Department of Education, and the NSF-Instrumentation for Laboratory Improvement Program (see also current and pending extramural support in Section IX.B).

\section{LIBRARY RESOURCES}

There are no standard disciplinary or accrediting agency requirements for library holdings in this relatively new research discipline. The library holdings as they currently exist in statistics, epidemiology, general and marine biology, and policy are overall adequate but need to be complemented by holdings specific to environmental studies. A continuing program of acquisition will create and routinely extend these resources. Other literature sources and resources are available within the cooperating departments as a result of acquisitions through their respective research programs. Books and journal articles unavailable at the MUSC and UCSC Libraries may be requested through interlibrary loan at no charge.

\section{A. Current Holdings}

\section{Library Resources at MUSC}

The Medical University of South Carolina Library collects print and nonprint materials in response to the needs of six colleges, and provides services -- both traditional and electronic - to meet the information needs of its users. The collection numbers 211,000 volumes, including books, serials, and audiovisual/nonprint items. Journal and serial titles currently received number 2,525 . The library adds 6,000 to 7,000 volumes per year.

The ACRL (Association of College and Research Libraries) standard does not normally apply to libraries that support schools awarding professional degrees, but the rule of thumb for the standard is that the basic collection should provide a minimum of 6,000 volumes per Master's degree offered.

As environmental information sources cover a myriad of field and subject areas, the proposed funds are viewed as a base amount to enable the MUSC library to add to their collection in subjects which have not been routinely collected. The amount is conservative in that there will be no attempt to collect exhaustively in any one of these fields. Nearly fifty subject headings were identified in environmental areas that would apply to resources for this 
program; the library has been either routinely or selectively collecting in about half of these areas.

\section{Library Resources at UCSC}

The Robert Scott Small Library at the University of Charleston, South Carolina more than meets the ACRL standards for the overall collection. It had 206,772 book volumes plus bound serials, fiche and film to equal 354,252 volume equivalents in June 1987, compared to a recommended standard of 214,340 volume equivalents for an institution its size. It acquires $13,000-14,000$ new volumes each year. The computerized card catalog, online database search services, interlibrary loan, and readily available reference librarians provide excellent services to the user.

\section{B. Qualitative Assessment}

The proposed program is in Environmental Studies, covering fields and subjects in which the library has only selectively collected. In preparation for this report, the following subject terms and keyword combinations were searched in MUSC's online catalog:

Air Pollutants, Environmental
Air Pollutants, Occupational
Carcinogens, Environmental
Environmental Epidemiology
Environmental Exposure
Environmental Health
Environmental Management
Environmental Medicine
Environmental Monitoring
Environmental Policy
Environmental Pollutants
Environmental Pollution
Environmental Protection
Environmental Psychology
Environmental Sciences
Environmental Toxicology
Environmentally Induced Diseases
Epidemiologic Methods
Hazard Assessment
Hazardous Substances
Hazardous Wastes
Health Physics
Health Risk Assessment

Air Pollutants, Environmental

Air Pollutants, Occupational

Carcinogens, Environmental

Environmental Epidemiology

Environmental Exposure

Environmental Health

Environmental Management

Environmental Medicine

Environmental Monitoring

Environmental Policy

Environmental Pollutants

Environmental Pollution

Environmental Protection

Environmental Psychology

Environmental Sciences

Environmental Toxicology

Epidemiologic Methods

Hazard Assessment

Hazardous Substances

Health Physics

Health Risk Assessment
Human Engineering
Industrial Hygiene
Industrial Toxicology
Models, Theoretical
Occupational Diseases
Occupational Exposure
Occupational Health
Occupational Health Services
Occupational Medicine
Operations Research
Probability
Programming, Linear
Radiation Monitoring
Radiation Protection
Radiometry
Risk
Risk Analysis
Risk Assessment
Systems Analysis
Systems Science
Systems Theory
Task Performance \& Analysis 


\section{Estimate of Needed Acquisitions}

There were 1,520 books, monographic serial titles, and audiovisual programs identified on these subjects in the MUSC online catalog, as well as 69 journal titles. Applying the ACRL standard, the volume count is only $25 \%$ of what it should be to support this program.

Only two bibliographies were searched: Environmental Health and Toxicology, A Selected Bibliography of Printed Information Sources, Public Health Service, Center for Disease Control, National Center for Environmental Health and Injury Control, Atlanta, GA, June, 1992. While the library holds some items from this bibliography in its collection, it would cost $\$ 52,000$ to purchase the remaining titles. The section on reference books, newsletters, and periodicals was quickly reviewed in the fourth edition of the Directory of Environmental Information Sources, ed. by Thomas Sullivan, Government Institutes, Rockville, MD, 1992. Forty six journal titles not held by the library were easily identified in support of this program at a total annual (recurring) cost of $\$ 13,000$. This is the cost for subscription only, without binding or maintenance. As noted here by their titles, neither of these sources covers all the subjects mentioned in the above list, relevant to a program in Environmental Studies. Annual cost for collections for the first five years could be estimated conservatively at $\$ 50,000$ per year.

In an analysis of the MUSC Library's current and past collection development practices as related to the listed subjects, the Library's approval plan profile allows for only selected collecting in systems science (analysis, probabilities, analytical methods), in chemistry (collecting primarily organic and biochemistry), in industrial, air, water, and sewage areas related to microbiology and immunology, in animal and plant poisoning and diseases/injuries caused by physical agents, and in health physics. In the subjects covered in the classification WA, or Public Health, the Library has collected routinely in Epidemiology, Preventive Medicine, Industrial Medicine, Occupational Health and Hygiene, but only selectively in Sanitation, Water and Food Supply, Air Sanitation, and Waste Disposal. Occupational Medicine is actively and routinely collected.

There is an unusual opportunity, considering the subject matter of this academic program to provide bibliographic information and actual information via the extensive use of databases. These databases would be available to students regardless of location (UCSC or MUSC) through the use of either the Library Information System or through the Microcomputer Labs. While the library presently has access to many online databases relevant to this program, there are several CD ROM products that might be considered. In addition, the enclosed list of TOXNET files are already planned to be incorporated into the 
Library's collection of available online databases, through the Department of Energy grant task force on databases.

\section{Library Datafiles: TOXNET Files}

Hazardous Substances Data Bank (HSDB)

A factual data bank focusing on the toxicology of over 4,300 potentially hazardous chemicals. Contains toxicity data, info in areas of emergency handling procedures, environmental fate, human exposure, detection methods, and regulatory requirements. Co-sponsored by the Agency of Toxic Substances and Disease Registry (ATSDR).

Registry for Toxic Effects of Chemical Substances (RTECS)

Contains toxic effects data on over 105,000 chemicals, covering both acute and chronic effects. Includes information on skin/eye irritation, carcinogenicity, mutagenicity, and reproductive consequences. Maintained by the National Institute for Occupational Safety and Health (OSHA).

Chemical Carcinogenesis Research Information System (CCRIS)

Scientifically evaluated data derived from carcinogenicity, mutagenicity, tumor promotion and tumor inhibition test on over 2,500 chemicals. National Cancer Institute.

Integrated Risk Information System (IRIS)

Contains EPA carcinogenic and non-carcinogenic health risk and regulatory information on over 450 chemicals. The risk assessment data have been scientifically reviewed by groups of EPA scientists and represent EPA consensus. Contains EPA Drinking Water Health Advisories, chemical and physical properties. Maintained by the Environmental Protection Agency (EPA).

Toxic Chemical Release Inventory (TRI)

Annual estimated releases of toxic chemicals to the environment. Data from industrial facilities nation-wide including names and addresses of the facilities, amounts of toxic chemicals they release to air, water and land or transfer to waste sites on over 300 chemicals and chemical categories. Data from the Environmental Protection Agency (EPA).

Directory of Biotechnology Information Resources (DBIR)

Information on a wide range of resources related to biotechnology including databases, networks, publications, organizations and collections \& repositories of cells and subcellular elements.

Genetic Toxicology (GENE-TOX)

Genetic toxicology test results on over 4,000 chemicals in the field of genetic toxicology, select mutagenicity assay systems, including source literature. Environmental Protection Agency (EPA). 
Environmental Teratology Information Center Backfile (ETICBACK)

Covers teratology literature with 49,000 citations (1950-1989) extended by DART. Oak Ridge Nat. Lab., ATSDR, EPA, NIEHS.

Developmental and Reproductive Toxicology (DART)

Covers teratology and developmental toxicology literature continuing ETICBACK. Oak Ridge Nat. Lab., ATSDR, EPA, NIEHS.

Environmental Mutagen Information Center Backfile (EMICBACK)

Covers literature on chemical, biological and physical agents tested for genotoxic activity containing over 70,000 citations (1950-1991). Oak Ridge Nat. Lab, EPA, NIEHS.

Library Datafiles: Natural Resources, Environment \& Health Files to be considered

Natural Resources Metabase. Over 45 U.S. Government databases covering wetlands, Pacific islands, eccsystems, national parks, resource management, resource development and expertise, etc. Produced by the National Information Services Corporation.

POLTOX Library (POLTOX I, II \& III: Pollution/Toxicology (Complete). Literature on pollution and toxicology with abstracts. Coverage is worldwide and covers ecology, food science and technology, health and safety, epidemiology, hazardous materials, pesticides and more. From Cambridge Scientific Abstracts.

Water Resources Abstracts Vol. I \& II. The Selected Water Resources Abstracts database from 1967, plus series of important water files licensed from sources around the world. National Information Services Corporation \& U.S. Department of the Interior, Geological Survey.

Health \& Medical Care Directory. Data on thousands of American health-related businesses and institutions nation-wide. From National Medical Yellow Pages. Produced by Innotech, Inc.

Biotechnology Abstracts. Covers the most significant scientific and technical aspects of biotechnology around the world. Includes comprehensive abstracts and patent coverage. Covers journal and conference literature in biotechnology.

OSH-ROM. Three databases on occupational health and safety information: US Nat. Institute of Occupational Safety \& Health (NIOSHTIC), UN International Labour Org (CISDOC), UK Health \& Safety Exec. (HSELINE). 240,000 citations from journals, books \& reports. From combined government reports. 
ENFLEX. Current compilation of federal \& state environmental regulations in full-text. Indexed by reference, applicability, date and requirement. Full text search.

OCLC Environment Library. Over 300,000 environment-related sources. 33\% published since 1989, with 4,000 covering materials published before 1900 . Searches by 20 separate access points (i.e., name, content, date). Source OCLC.

Physicians' Data Query (PDQ)/CANCERLIT. State-of-the-art treatment recommendations for 80 types of cancer, over 1,100 cancer treatment protocols and directories listing 12,000 physicians and 1,500 organizations involved in cancer treatment. Three files: Cancer information file, Protocol file, and Directory file. Practical, therapy-oriented database developed by over 400 cancer specialists. National Cancer Institute.

Kirk-Othmer Encyclopedia of Chemical Technology. 3rd Ed. Standard reference work on chemistry and the chemical industry, containing over 1,000 articles from the 26 volumes print version, plus supplements, indexes, abstracts and 6,000 tables. Dialog/Kirk-Othmer.

TOMES. Industrial chemical database. Covers clinical effects, range of toxicity, workplace standards, kinetics \& physiochemical parameters in-depth. Comprehensive, referenced protocols for medical evaluation \& treatment of individuals exposed to chemical agents.

Science and Technical Reference Set 2.0. Texts from the Concise Encyclopedia of Science \& Technology, 2nd Ed. and Dictionary of Scientific and Technical Terms, 4th Ed. providing concise, authoritative and accurate coverage of 75 major disciplines of science and engineering via full-text search by Hyper Text 'Links' between associated items. McGraw-Hill Publishing Co.

EI ENERGY \& ENVIRONMENT. Includes meteorology, air \& water pollution, sewage \& industrial wastes treatment, geology \& geophysics, petroleum, nuclear technology, power plants \& generators.

Health Devices Alerts. 135,000 records warning buyers of hazards associated with devices. Four files: 1 . Action Items - confirmed hazards \& recalls investigated by ECRI, 2. Abstracts of reported problems, evaluations, technology assessments, 3. MDRs, complete Med Device Reports from U.S. Food and Drug Administration, 4. PRP's, FDA's Problem Reporting Program reports. Source ECRI.

GEOREF. 1.5 million citations covering the geology of North America since 1785 and the world since 1933 from 3,000 journals \& Geological Survey pubs. From American Geological Institute, Index of Geology, Bib. of N.A. Geology, and Geophysical Abstracts. Amer. Geol. Institute. 
Geological Survey - Annual. 55,092 references to USGF reports and maps (1880$1990), 15,227$ to non-Survey pubs. Incl. Hayden, King surveys. Amer. Geol. Institute.

PEST-BANK. 45,000 U.S. registered pesticides used in agriculture, industry, and general commerce. Names \& systems, registration dates \& registering companies, composition \& formulation, sites \& pests. From National Pesticide Info. Retrieval System (NIPIRS).

CCINFODISC/RTECS. Registry of Toxic Effects of Chemical Substances (RTECS) gives toxicity data for over 110,000 substances. Heath hazard data, occupational exposure survey data \& regulatory information. Produced by the Nat. Inst. Occupational Safety \& Health (NIOSH).

\section{ACCREDITATION, APPROVAL, LICENSURE, OR CERTIFICATION}

The program will lead exclusively to the Master's degree. Questions of accreditation, approval, licensure, or certification therefore are not applicable.

\section{ESTIMATED ADDITIONAL COST}

A memorandum of understanding between MUSC and UCSC has internally clarified the responsibilities of and resources for each of the two institutions, as they relate to this proposal and to currently available DOE funds (see also Section V.G). According to this agreement, faculty positions will be made available at each institution, and both institutions will be represented in the administration and governance of this proposal. The fact that the DOE grant was awarded to MUSC should not be construed as an indication that MUSC would be the dominating force behind this proposal. It is noted that the DOE grant encompasses several tasks among which the development of educational programs is just one. Of the budget for educational purposes, a significant portion has been subcontracted to UCSC. As negotiated and documented in the memorandum of understanding between MUSC and UCSC, the proposed program will be a true joint venture with two equal partners.

\section{A. Table of Expenditures}

We propose to hire a Program Director who will be appointed jointly to MUSC and UCSC (cf. Section V.G). Additional faculty required to staff the 
program are listed by both headcount and FTE. Faculty hired will be appointed at either MUSC or UCSC. Our specific intentions for the distribution of FTE's are outlined in Table 7.

We have also included cost estimates for clerical staff and support activities (e.g., telephone). Furthermore, we have added cost estimates for faculty and student travel to scientific and policy-oriented meetings, as well as costs for recruiting graduate students. These travel funds will be administered as discussed in Section V.F.

The librarians at both institutions have formed a joint advisory committee to help them in selecting items for inclusion in the libraries at the two institutions. As environmental information sources cover a myriad of field and subject areas, the proposed $\$ 50,000$ per annum are viewed as a base amount to enable the MUSC library to add to their collection in subjects which have not been routinely collected. The amount is conservative in that there will be no attempt to collect exhaustively in any one of these fields. Nearly fifty subject headings were identified in environmental areas that would apply to resources for this program; the library has been either routinely or selectively collecting in about half of these areas.

According to DOE guidelines, the allotment for library acquisitions $(\$ 50,000$ per annum) has to be utilized at MUSC. However, an agreement has been reached between the institutions for using indirect cost moneys to support the UCSC library in relevant environmental areas.

Table 7: ESTIMATED BUDGET

Item

1994-95

1995-96

1996-97

1997-98

1998-99

Salaries

Program Director (No., Headcount) 1

(No., FTE)

1

Cost

$\$ 72,000$

1

$\$ 76,320$

1

$\$ 80,899$

1
1
$\$ 85$

1

1

Additional Faculty

(No., Headcount)

(No., FTE)

10

6.7

10

7.5

12

7.5

12

7.5

12

Cost

$\$ 301,500$

$\$ 357,750$

$\$ 379,215$

$\$ 401,968$

7.5

$\$ 90,898$ 
Clerical Assistant

Cost

$\$ 20,000$

$\$ 21,000$

$\$ 22,472$

$\$ 23,820$

$\$ 25,250$

Fringe Benefits

( $25 \%$ of Salaries)

$\$ 98,375$

$\$ 113,818$

$\$ 120,647$

$\$ 127,885$

$\$ 135,558$

Equipment and Supplies; Other

$\begin{array}{lrrrrr}\text { Equipment } & \$ 133,340 & \$ 133,340 & \$ 133,340 & \$ 133,340 & \$ 133,340 \\ \text { Travel } & \$ 22,000 & \$ 22,000 & \$ 25,000 & \$ 25,000 & \$ 25,000\end{array}$

[ $\$ 2,000$ (program director); $\$ 1,500$ (per faculty); $\$ 5,000$ (graduate students)]

\begin{tabular}{|c|c|c|c|c|c|}
\hline Telephone & $\$ 5,000$ & $\$ 5,250$ & $\$ 5,513$ & $\$ 5,788$ & $\$ 6,078$ \\
\hline Library & $\$ 50,000$ & $\$ 50,000$ & $\$ 50,000$ & $\$ 50,000$ & $\$ 50,000$ \\
\hline $\begin{array}{l}\text { Physical Plant } \\
\text { (office furniture) }\end{array}$ & $\$ 33,000$ & 0 & 0 & 0 & 0 \\
\hline $\begin{array}{l}\text { Recruitment of } \\
\text { Graduate Students }\end{array}$ & s $\$ 5,000$ & $\$ 5,250$ & $\$ 5,513$ & $\$ 5,788$ & $\$ 6,078$ \\
\hline Cotal & $\$ 740,215$ & $\$ 784,728$ & $\$ 822,599$ & $\$ 859,342$ & $\$ 89$ \\
\hline
\end{tabular}

\section{B. Sources of External Funds}

While initial funding for this program has been provided by a substantial grant from the Department of Energy, it is recognized that these funds are to be considered seed moneys for obtaining independent extramural support. As concerns this proposal, funds outside the DOE grant will come from four sources: training grants, research grants, instrumentation grants, and tuition. Both institutions have a track record of successfully obtaining extramural funds on a regular basis. One DOE training grant has already been secured. MUSC has also been successful in obtaining NSF funds for student summer research and NIH funds for student training. These funds are relevant for the proposed educational program. Furthermore, MUSC offers specific grants for minority students.

In addition to the funds provided by the DOE grant, MUSC is holding about $\$ 200,000$ in extramural funds for training grants that could be applicable to 
the Environmental Studies Program. Moreover, MUSC holds extramural grants exceeding $\$ 500,000$ that are being used for faculty salaries and research costs. MUSC has just made a sizable investment for a chairman in Biometry and Epidemiology. There is every indication that he will generate significant extramural funds in the areas of environmental epidemiology and risk assessment.

The Department of Biometry and Epidemiology with support of the University's administration, has been responsive to the need of obtaining extramural funds outside the DOE grant by implementing plans to expand the teaching and research faculty in areas related to environmental risk assessment. The following projects are currently being extramurally funded or pending.

a) Geographic Information System for Examining Potential Linkages Between Health \& Environmental Outcome Effects and Hazardous Waste Management

P.I.: $\quad$ M. Clinton Miller, III, Ph.D., Co-P.I.: Zhen Zhang, Ph.D. Sponsor: SC University Research and Education Foundation (SCUREF) Status: $\quad$ Planning grant completed; pending 3 years Amount: $\quad \$ 505,068$ (3 Years)

This project proposes to develop a Geographic Health Information System (GHIS) consisting of a Geographic Disease Information System and a Site Profile Information System. These systems will be designed to assess health and environmental risks associated with the storage, recycling and management of hazardous waste products. This proposal will serve as the foundation for education programs designed to elevate awareness of environmental and health effects of hazardous waste materials among waste managers, policy makers, lay public, community and students.

b) Continuing Health Surveillance of Employees of the Savannah River Plant. P.I.: $\quad$ Thomas Hulsey, D. Sc., Co-P.I.: M. Clinton Miller, Ph.D.

Sponsor: SC University Research and Education Foundation (SCUREF) Status: Planning Grant completed; pending 2.25 years

Amount: $\$ 553,381$

This contract with the Westinghouse Corporation is administered through SCUREF. It provides continued health surveillance of active and pensioned employees of the Savannah River Nuclear Production Plant. A health experience registry containing selected medical and health information on all active and pensioned employees has been acquired by Westinghouse from the previous plant contractor (DuPont) and attendant health insurance carriers. In addition, certain reproductive health information on female employees and wives of male employees has and is continuing to be collected. The research team at MUSC provides technical assistance in the surveillance of this registry and evaluating published reports on health and radiation exposures. 
c) DOE/EPSCoR Graduate Research Traineeship

P.I.: $\quad$ M. Clinton Miller, III, Ph.D., Co-P.I.: Daniel Lackland, D.P.H.

Amount: $\quad \$ 31,250$ (Two Years)

The South Carolina State EPSCoR Committee has recently funded a DOE/EPSCoR Graduate Traineeship in Biometry and Epidemiology. Significant aspects of this traineeship grant are: First, the student is required to take a practicum, (approximately three months) at a DOE national laboratory or facility. The other requirement is that the student's $\$ 18,000$ annual stipend includes $\$ 6,000$ as a match, in addition to approximately $\$ 9,625$ in matching funds for materials and supplies, publication costs, instrument maintenance, computer time, etc. This is further documentation of this University's commitment to develop research and educational expertise in environmental health related issues of interest to DOE.

d) Cancer and Birth Defects Surveillance System for Communities

Around the Savannah River Site

P.I.: $\quad J o h n$ B. Dunbar, Dr. P.H., Co-P.I.: Daniel T. Lackland, D.. P.H.

Sponsor: DOE

Amount: $\quad \$ 2,002,000$ (Three Years)

The goals of the Savannah River Region Health Information System (SRRHIS), developed under this grant, are: (1) To assemble and report cancer incidence in the 25 contiguous counties along the Savannah River; (2) To disseminate the assembled information to hospitals, physicians, public and political sectors of the region and States; (3) To monitor cancer incidence in the SRRHIS region in order to identify unusual changes in specific cancers occurring in population subgroups defined by geographic, demographic, and social characteristics; (4) To evaluate the effects of overall cancer control efforts by examining information on changes over time in the amount of cancers of specific types, and in the extent of disease at the time of diagnosis; (5) To provide passive follow-up of patients through mortality surveillance in order to determine survival by type of cancer; (6) To promote research to identify factors related to cancer control such as: environmental, social, dietary, occupational effects; early detection and treatment needs; determinants of length of patient survival and quality of life.

e) Nonlinear Physiologically-Based Pharmacokinetic Modeling

P.I.: $\quad$ Eberhard O. Voit, Ph.D., Co-P.I.: M. Clinton Miller, Ph.D.

Sponsor: $\quad$ SC EPSCoR (DOE)

Status: Pending

Amount: $\quad \$ 737,041$ (Two Years)

This project is concerned with the analysis of the fate of toxicants that enter the human body. Currently the most promising approach to dealing with 
this problem is physiologically-based pharmacokinetic (PB-PK) modeling. Specific aims address several aspects of improving current PB-PK models and of implementing them in user friendly software.

It is noted that one of the primary investigators in this project is at Clemson University.

\section{Unique Costs}

No "unique" costs or other special State appropriations will be required or requested.

\section{Relationship to Deficiencies in Current Programs}

Upon recommendation from the South Carolina Commission on Higher Education, the Medical University of South Carolina has, effective 8 January 1993, combined the following Master's programs into a single Master of Science in Biomedical Sciences program: Cell Biology and Anatomy, Biochemistry and Molecular Biology, Microbiology and Immunology, Pathology and Laboratory Medicine, Cell and Molecular Pharmacology and Experimental Therapeutics, Physiology, and Biostatistics, Epidemiology, and Systems Science. The combining into a single program had been recommended by the South Carolina Commission on Higher Education because of low enrollment in the former programs. The combining of the above programs did not require additional resources nor alterations in basic rules and regulations governing the programs.

Attention has been given, in general, to the suggestion from the South Carolina Commission on Higher Education that the problem of Pinadequate research space at UCSC be addressed. Faculty hired into the School of Sciences and Mathematics in recent years have been provided with computers and/or modest start-up funds to initiate research programs. In many cases specific research space has been designated as "faculty/student" research space. This has enabled UCSC to remain competitive in hiring highly qualified faculty. 


\section{INSTITUTIONAL APPROVALS}

Medical University of South Carolina

Approved by:

Dean

Graduate Counil

Graduate Faculty

Academic Council

President's Council

Board of Trustees
Date:
$11 / 16 / 92$
$12 / 16 / 92$
$01 / 08 / 93$
$01 / 11 / 93$
$01 / 27 / 93$
$02 / 12 / 93$

University of Charleston, South Carolina

Approved by:

Graduate Council

Graduate Faculty

Board of Trustees
Date:

$2 / 23 / 93$

$2 / 23 / 93$

$1 / 15 / 93$ 

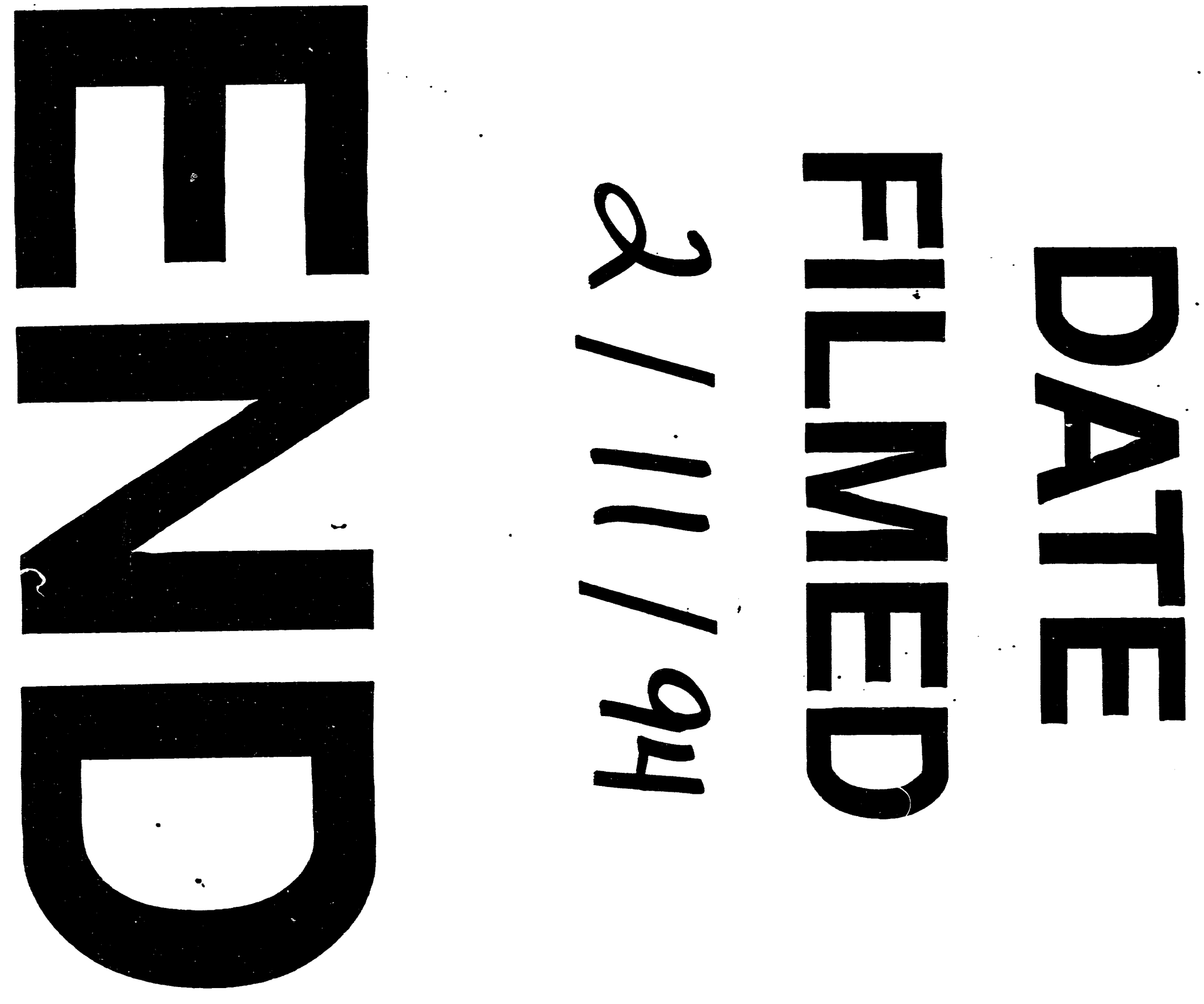
